\title{
A prodeltaic system controlled by hyperpycnal flows and storm waves: reinterpretation of the Punta Negra Formation (Lower-Middle Devonian, Argentine Precordillera)
}

\author{
Um sistema deposicional de prodelta dominado por fluxos hiperpicnais \\ e ondas de tempestade: reinterpretação da Formação Punta Negra \\ (Devoniano médio-inferior, Pré-Cordilheira Argentina)
}

Pedro Henrique Vieira de Luca ${ }^{1}$, Giorgio Basilici ${ }^{2 *}$

\begin{abstract}
The Punta Negra Formation (FPN) constitutes a Lower-Middle Devonian sandstone unit located in the Argentine Precordillera. Based on detailed facies and ichnological analyses, this unit, which had been previously interpreted as a deep-water system, has been reinterpreted in this study as a prodelta system, in which the distribution and sedimentation of the clastic deposits were controlled by hyperpycnal flows associated with storms. Five lithofacies attest the deposition by unidirectional hyperpycnal flows combined with storm-generated oscillatory flows. Fossil traces testify variable energetic conditions of the depositional system with the colonization of opportunistic organisms immediately after the deposition of high energy combined flows and the colonization of more specialized organisms during the long low-energy periods. Three architectural elements, deposited from coastline to offshore, have been recognized: 1) Channelized sandstone, composed of the thickest and coarsest sandstone beds and interpreted as the proximal portion deposited close to the mouth of the distributaries of the delta system;2) Tabular sandstone, which are composed of combined and oscillatory flow deposits with lesser thickness, grain size and spacing of the undulated bed forms; 3) Tabular sandstone interbedded to mudstone, which represents the most distal architectural element and is composed of thin sandstone and thicker mudstone strata, deposited by low-energy combined flows.
\end{abstract}

KEYWORDS: combined flows; hummocky cross-stratifications; ichnology.
RESUMO: A Formaçāo Punta Negra (FPN) constitui uma unidade arenitica do Devoniano médio-superior e pode representar um exemplo antigo de uma unidade sedimentar depositada em um sistema de prodelta dominado por ondas. A FPN foi previamente interpretada como um sistema deposicional marinho profundo, produto de sedimentação gerada por fluxos turbidíticos. Contudo, neste trabalho foi reinterpretada como sistema deposicional de prodelta influenciado pela atividade de ondas de tempestade. As cinco litofácies descritas foram geradas por processos que resultaram da combinaçāo de fluxos unidirecionais hiperpicnais e oscilatórios, decorrentes de tempestades. Os icnitos sugerem alternância das condiçôes dinâmicas do ambiente, que passavam de momentos de alta energia, relacionados aos fuxos combinados, seguidos pela colonização de organismos oportunistas, para momentos de calmaria, seguidos da colonização de organismos mais especializados. Três elementos arquitetônicos depositados da costa até costa-afora foram reconhecidos: 1) Arenitos canalizados, compostos pelos estratos de arenitos mais espessos e grossos, e interpretados como a porção proximal depositada perto da desembocadura de canais distributários de deltas; 2) Arenitos tabulares, compostos por depósitos de fluxos combinados e oscilatórios, sendo caracterizados por menores espessuras, granulaçōes e espaçamentos das formas unduladas da superficie das camadas; 3) Arenitos tabulares intercalados a pelitos, que representam o mais distal elemento arquitetônico e que é composto por camadas sutis de arenitos e mais espessas de pelitos, depositadas por fluxos combinados de baixa energia.

PALAVRAS-CHAVE: fluxos combinados; estratificaçōes cruzadas bummocky; icnologia.

\footnotetext{
${ }^{1}$ Programa de Pós-Graduação em Geociências, Instituto de Geociências, Universidade Estadual de Campinas - Unicamp, Campinas (SP), Brasil. E-mail:pedro.luca@gmail.com

${ }^{2}$ Instituto de Geociências, Universidade Estadual de Campinas - Unicamp, Campinas (SP), Brasil. E-mail: basilici@ige.unicamp.br

*Corresponding author

Manuscrito ID 30022. Recebido em: 19/08/2013. Aprovado em: 18/11/2013.
} 


\section{INTRODUCTION}

The interpretation of deposits formed in storm-dominated marine shelf and produced by combined flows (combination of oscillatory and unidirectional flows) does not have a simple resolution. Actually, since the 1970s it is object of discussion (Hamblin \& Walker 1979, Dott \& Bourgeois 1982, Leckie \& Krystinik 1989, Higgs 1991, Myrow et al. 2002, Myrow et al. 2008, Lamb et al. 2008). One of the most important arguments is related to the sediment transport and the evolution of the depositional flows across the shelf. The oceanographic vision stresses that the sediment transport occurs parallel to the coast by the geostrophic currents (Figueiredo 1980, Parker 1982, Swift 1985, Swift et al. 1986, Snedden et al. 1988, Snedden \& Swift 1991). The geological vision, based on the analysis of ancient sedimentary successions, suggests that the sediment was transported orthogonally across the shelf to the coastline as a result of the coastal setup (Hamblin \& Walker 1979, Leckie \& Walker 1982, Leckie \& Krystinik 1989, Myrow 1992, Myrow \& Southard 1996).

Another matter of discussion is related to the features and sedimentary structures formed in depositional environments influenced by the combined-flow. These deposits may be very similar to those formed in deep waters by gravitational flows (Hamblin \& Walker 1979, Dott \& Bourgeois 1982, Walker 1984) and the distinction between them is not clear. Indeed, studies on sedimentary processes and structures yielded by combined flows (Arnott \& Southard 1990, Yokokawa et al. 1995, Dumas et al. 2005, Yamaguchi \& Sekiguchi 2010) have justified the reinterpretation of sedimentary successions, previously interpreted as deep-water depositional systems, as successions deposited in marine shelf under storm influence (Higgs 1991, Bhattacharya et al. 2004, Pattison et al. 2007, Lamb et al. 2008, Myrow et al. 2008, Basilici et al. 2012b).

In this paper, the Punta Negra Formation (PNF), which had been previously interpreted as typical deep-water fan, is considered as a prodeltaic system, which was controlled by combined flows, induced by the association of hyperpycnal flows and storm waves.

\section{Geological Setting}

The PNF consists of a succession of sandstone and mudstone, approximately 1,000 m thick, deposited during the Devonian in the geological context of the Argentine Precordillera (APC) (Fig. 1). The APC is probably an allochthonous terrane that resulted of a rifting of the southern margin of the Laurentia plate and the subsequent accretion into the western margin of Gondwana (Keller et al. 1998, Rapela et al. 1998, Keller 1999, Thomas \& Astini 2003). The PNF was deposited in a foreland basin in front of an orogenic belt. Keller et al. (1998) stressed that the Devonian sediments of the PNF represent the end-phase of the accretion of this terrain to Gondwana, whereas Cuerda et al. (1990) and Bustos and Astini (1997) stated that this foreland basin was generated by the collision of another terrain (Chilenia) into the Gondwana.

Gonzales Bonorino and Middleton (1976), Ramos and Vujovich (2000) interpreted the PNF as deposits resulting from sediment gravity flows that formed a deep-water fan. Bustos (1996) and Bustos and Astini (1997) described this unit as a prodeltaic system prograding towards a muddy ramp. These authors cited the presence of hummocky cross-stratifications (HCS) produced by storm deposits. Poiré and Morel (1996) and Edwards et al. (2009), based on ichnological criteria, suggested a deposition in a proximal environment, which was influenced by storm waves. Basilici et al. (2012b) showed sedimentological evidence suggesting that this unit deposited in a shallow-water shelf, which was influenced by hyperconcentrated flows and storm waves.

\section{METHODS}

Thirty-six outcrops were examined and 12 sections were measured and analysed. The study areas are located on the central APC, along a N-S $90 \mathrm{~km}$ long zone, near the city of San Juan, and in the Talacasto location (Fig. 1). To recognize the main depositional processes, a detailed facies analysis was executed to define texture, sedimentary structures, bounding surfaces, and geometry of the beds according to the recommendation of Miall (1985), Walker (2006), and also taking into account the comments of Bridge (1993). Two hundred and thirty-seven paleocurrent direction values were collected. Twenty-six rock samples were cut in slabs and 13 thin sections were used to recognize the texture and the mineralogical component of the sandstone. Ichnofossil identification has been preliminary performed in the field. Other detailed analyses were conducted in laboratory, where the ichnofossils were characterized and described by rock samples and photos. The ichnofabric index was quantified in the field and in the laboratory according to Pemberton et al. (1992). One hundred and seventy photos helped to identify and characterize lithofacies and ichnites.

\section{LITHOFACIES}

The description of five lithofacies follows.

\section{Graded and thick sandstone}

This lithofacies constitutes $4 \%$ of the thickness of the measured sections. This consists of graded sandstone beds, 
medium- to very fine-grained, $1.1-3 \mathrm{~m}$ thick (Fig. 2A). Their lateral N-S extension is $70-130 \mathrm{~m}$. The lower surface is erosive, incised up to $2.2 \mathrm{~m}$ (Fig. 2B). Groove marks and gutter casts are common on the lower surface. Beds may be subdivided into three portions (Fig. 2A). The lower portion has $50-90 \%$ of the thickness and is constituted of structureless, medium- or fine-grained sandstone. In the basal $0.25 \mathrm{~m}$ of the beds, inverse grading is commonly observed. Locally, planar or undulated parallel laminations occurs. The intermediate portion has $5-35 \%$ of the thickness of the bed, and is constituted of well-sorted fine- or very fine-grained sandstone, which forms planar, very low-angle or undulated parallel laminations. The upper surface of the beds is undulated, with $4-12 \mathrm{~m}$; locally, it is covered by cross-laminations dipping at low-angle $\left(<10^{\circ}\right)$ with sigmoidal form. These constitute ripple bedforms, $15-25 \mathrm{~mm}$ high, $0.08-0.15 \mathrm{~m}$ spaced, with rounded crest, and low symmetry index. The upper portion is formed by structureless sandy mudstone, $10-15 \mathrm{~mm}$ thick.

Interpretation: The structureless sandstone is probably deposited by high suspended-load fallout rate, which inhibited the formation of structures. The inverse grading at the beginning of the sedimentation suggests the early phase of waxing flow, followed by a gradual waning flow. Similar

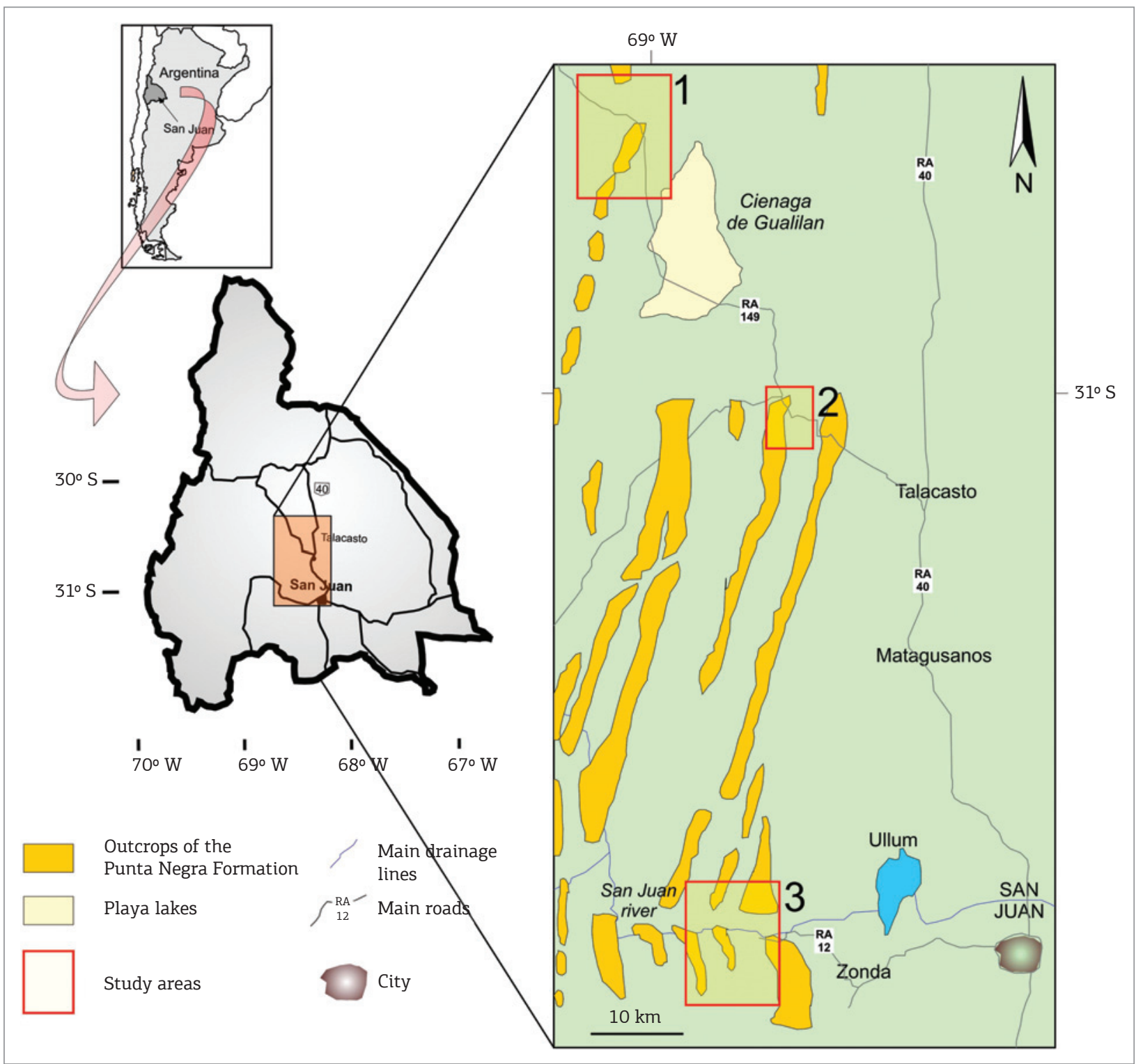

Figure 1. Location of the PNF in the province of San Juan. This unit shows N-S aligned outcrops, which are related to the Argentine Precordillera Range. 
planar-parallel, low-angle and undulated laminations of the lower and intermediate portions were reproduced in flume studies by Arnott and Southard (1990) and observed in rocks (Arnott 1993). They are interpreted as being formed by high-energy combined flows in plane bed regime. Ripples with low-angle foresets and short wave-length may have been generated by low-energy combined-flows (Massuda \& Yokokawa 1993, Yokokawa 1995, Dumas et al. 2005). The sandy mudstone represents the end-stage of sedimentation by settling.

\section{Sandstone with undulated laminae}

This lithofacies constitutes $8 \%$ of the thickness of the measured sections, and it is constituted of well-sorted litharenite or sublitharenite, fine- or very fine-grained, with angular or subangular grains. The beds are $0.1-1 \mathrm{~m}$ thick, their base is plane and abrupt (Figs. 3A and B). Locally, the base may be erosive, up to $5 \mathrm{~m}$ wide and $0.3 \mathrm{~m}$ deep. The top surface displays regular undulation, $3-12 \mathrm{~m}$ spaced and $0.1-$ $0.32 \mathrm{~m}$ high. The bed can be subdivided in two portions (Fig. 3A). The lower portion, which represents $60-100 \%$
A

$2 \mathrm{~m}$

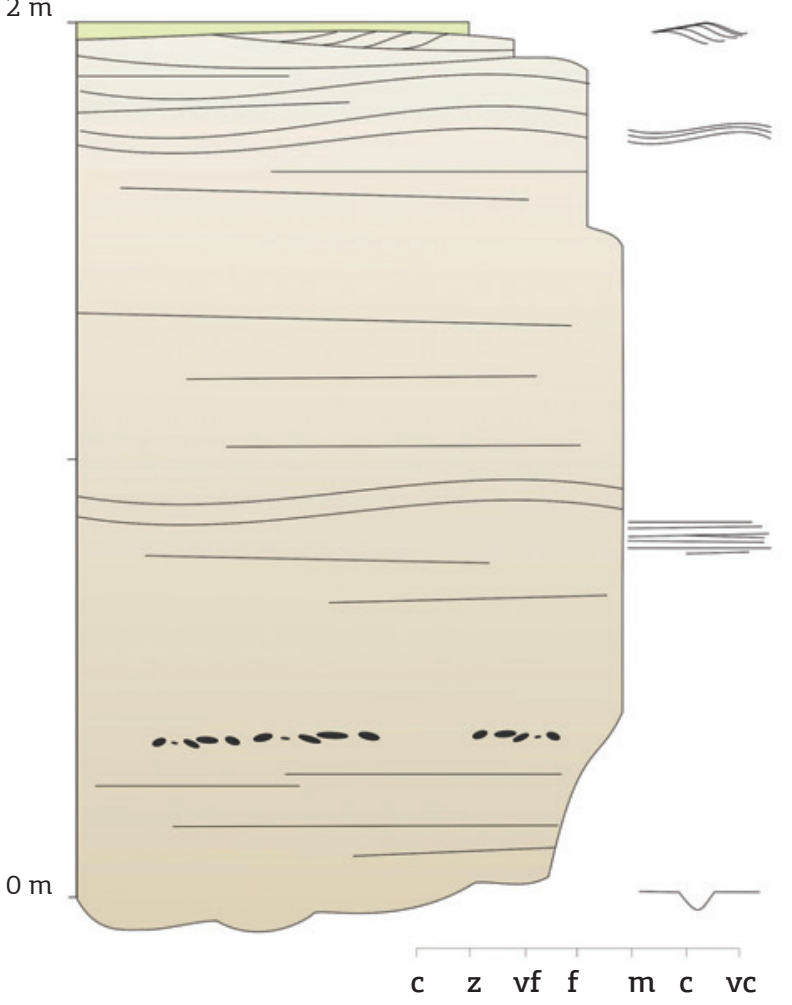

B

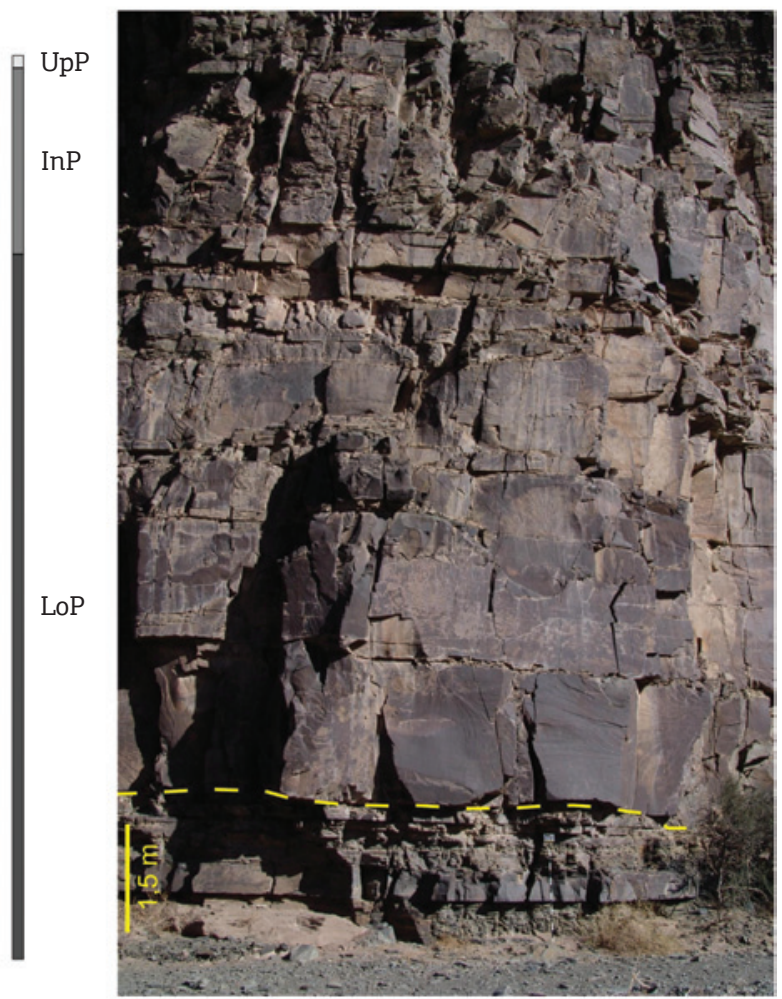

\begin{tabular}{|c|c|}
\hline 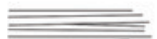 & Quasi-parallel lamination \\
\hline$\Longrightarrow$ & $\begin{array}{l}\text { Undulated laminations, } \\
\text { weakly asymmetrical }\end{array}$ \\
\hline UpP & Upper portion \\
\hline InP & Intermediate portion \\
\hline LoP & Lower portion \\
\hline
\end{tabular}

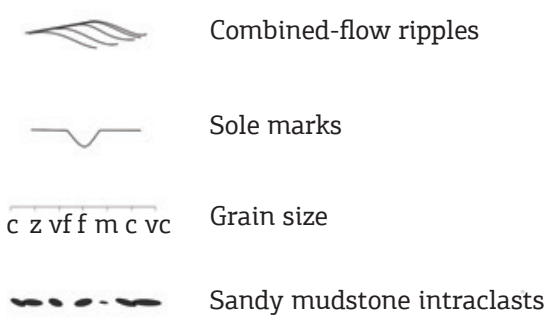

Figure 2. Graded and thick sandstone beds. (A) Graphic sketch of lithofacies. (B) This lithofacies displays an erosive base (dotted line). 
of the thickness, is composed of well-sorted, fine-grained sandstone, organized in graded laminae, which display muscovite and vegetal remains at the top. The laminae are parallel, gently undulated and locally planar; they form gentle hummocks and swales with analogous spacing and height of the top surface. Their thickness and grain size decrease towards the top: from 1 to $40 \mathrm{~mm}$ and from fine-grained to very fine-grained sandstone, respectively (Fig. 3C). Gentle cross-stratification can be observed from the hummock to the swale; their dip direction is bimodal or multimodal. At times, two or three laminae sets with erosive base occur,
$0.1-0.6 \mathrm{~m}$ thick. Locally, low-angle $\left(5-15^{\circ}\right)$, sigmoidal cross-laminations, $5-20 \mathrm{~mm}$ thick, are interbedded with the laminae. Similar cross-laminations form small and flat ripples at the top surface of the bed (Fig. 3D). The upper portion $(0-40 \%)$ of the thickness is constituted of structureless sandy mudstone, $0.01-0.1$ m thick.

Interpretation: The undulated laminae are interpreted as accretionary hummocky cross-stratification-like (HCSlike) structures, which may be deposited by high energy oscillatory flows, as indicated by the height and long spacing of the undulation (Brenchley \& Newall 1982, Craft \&

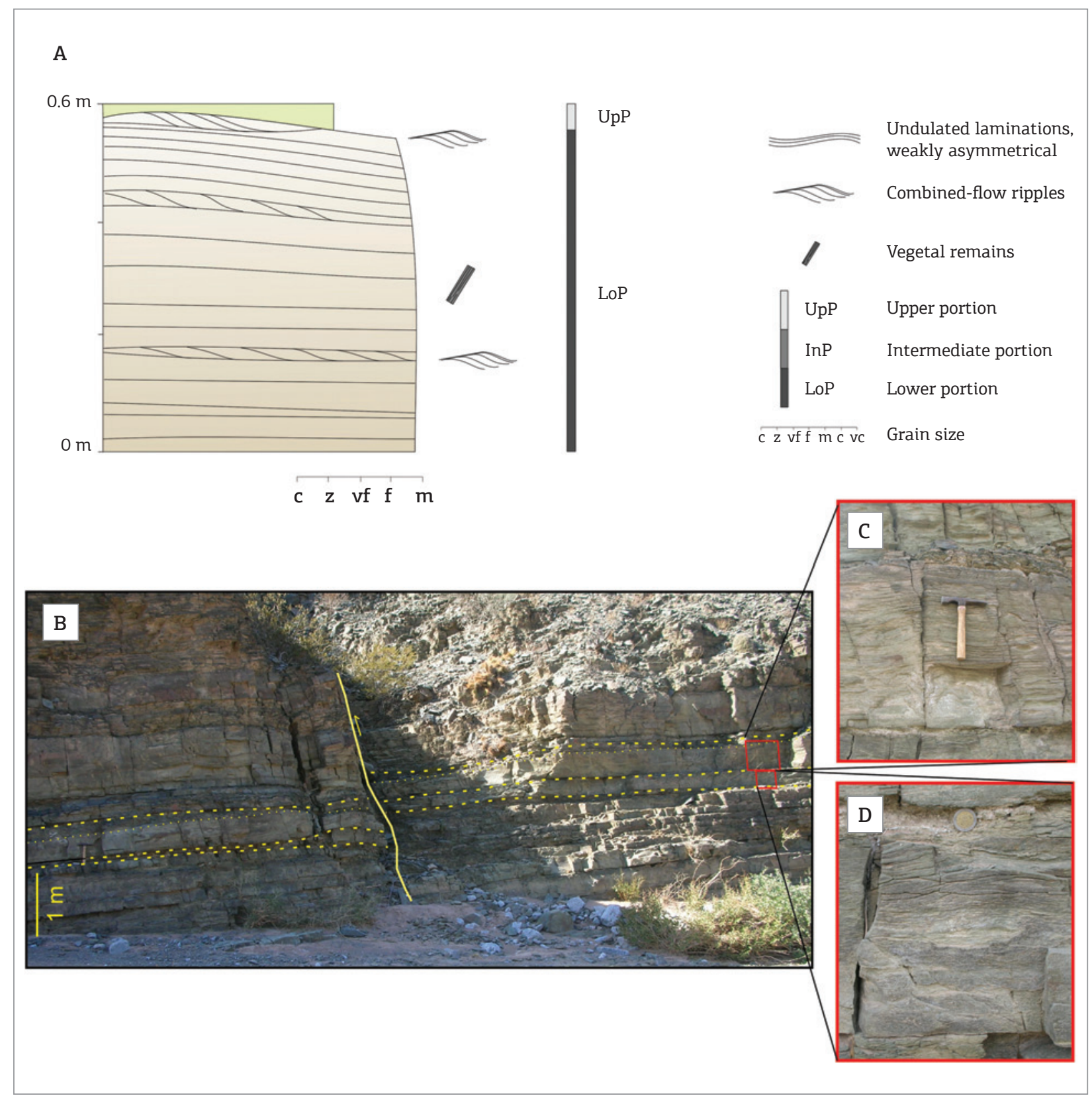

Figure 3. Sandstone with undulated laminae. (A) Graphic sketch of lithofacies. (B) Two amalgamated beds, whose boundaries are indicated by dashed lines. The thin dotted line indicates the boundaries of the lower and upper portions. (C) Undulated laminae. Hammer: 0.28 m. (D) Small combined-flow ripples at the top of the bed. Coin: $23 \mathrm{~mm}$. 
Bridge 1987, Cheel \& Leckie 1993, Basilici et al. 2012a). The beds of these lithofacies reflect a vertical accretion in high sedimentation rate and with weak or no unidirectional component of the flow. The upward decrease in grain size and lamina indicate waning flows. The interbedded sets of low-angle cross-laminations, which can be interpreted as combined-flow ripples, indicate flow velocity variation and influence of a unidirectional component.

\section{Sandstone with HCS}

The beds of this lithofacies are $0.09-1.35 \mathrm{~m}$ thick, representing $57 \%$ of the thickness of the measured sections. They are constituted of litharenite or sublitharenite. Each bed may be subdivided in three portions (Fig. 4A). The lower portion, $30 \%$ of the thickness of the bed, consists of a medium fine-grained sandstone organized in planar, undulated or low-angle parallel laminations. The laminae sometimes display grading. At the base of the bed, an inverse grading (very fine- to medium-grained sandstone), a few centimeters thick, is commonly observed. On the sole of the beds, flute casts, longitudinal ridge and furrow casts occur (Dzulynski 1965, Allen 1984), as well as gutter casts (Fig. 4B). The intermediate portion is a fine-grained sandstone, displaying symmetrical or gently asymmetrical, undulated laminations, $1-3 \mathrm{~mm}$ thick, which are constituted of small hummocks and swales, $20-90 \mathrm{~mm}$ high, with spaces of $0.5-2.7 \mathrm{~m}$ (Fig. 4C). Locally, sets of low-angle cross-laminations are interbedded with these laminations. The upper portion is constituted of structureless sandy mudstone, $10-70 \mathrm{~mm}$ thick. Relatively common synsedimentary deformations are composed of open or closed, small convolute laminations up to recumbent folds, which, in general, show vergence parallel to the paleocurrent indicators (Fig. 4D).

At times, a subtle variation of lithofacies could be observed (Fig. 5). These are constituted of fine-grained sandstone grading to sandy mudstone, $0.2-0.8 \mathrm{~m}$ thick, which display two-five sets of undulated laminations with erosive base (Fig. 5). Even in the variation of this lithofacies, the undulated laminations may be interbedded by sets of cross-laminations with low-angle foresets.

Interpretation: The beds of this lithofacies were deposited by oscillatory flows and partially combined flows. The planar, undulated and low-angle parallel lamination may be interpreted as quasi-planar lamination of Arnott and Southard (1990) and Arnott (1993), and the symmetrical or gently asymmetrical undulated laminations, as accretionary HCS (Brenchley \& Newall 1982, Craft \& Bridge 1987, Cheel \& Leckie 1993, Bhattacharya \& Bhattacharya 2005). The organization of the structures in the bed indicates that the deposition occurred for oscillatory and combined flows, with decreased orbital velocity during deposition (Myrow
\& Southard 1991). The inverse grading at the base of the beds suggests a gradual increase in velocity of the flow at the beginning of sedimentation, which is affirmed by the sole marks that record turbulent flows of low energy and poor erosive capacity. Cross-laminations interbedded with planar and undulated laminations testify the fluctuation of the flow energy during the deposition.

The sets of undulated laminations with erosive base which constitute a subtle variation of the lithofacies are interpreted as scour and drape HCS (Cheel \& Leckie 1993), testifying the deposition for high energy oscillatory flows alternated to erosive processes (Craft \& Bridge 1987).

Convolute laminations are associated with sand liquefaction due to the cyclic and residual storm waves (Molina et al. 1998). The asymmetrical folds suggest the action of a unidirectional shear, which is part of the hydraulic flows (Myrow et al. 2002).

\section{Sandstone with anisotropic HCS}

This lithofacies is composed of grading, fine- to very fine-grained sandstone, forming $0.08-0.32 \mathrm{~m}$ thick beds, which represent $7 \%$ of the measured sections. Groove cast and longitudinal ridge and furrows occur at the sole of the beds. The beds can be subdivided in three portions (Fig. 6A). The lower portion, representing up to $70 \%$ of the thickness of the bed, is constituted of planar, undulated or low-angle parallel laminations. Each lamina is normally graded from fine- to very fine-grained sandstone. The intermediate portion $(15-56 \%$ of the thickness) is organized in asymmetrical undulated laminations, which display $0.2-0.35 \mathrm{~m}$ of spacing and $0.08-0.12 \mathrm{~m}$ high. These laminations show a vertical and lateral transition to cross-laminations with low-angle foresets, whose spacing is $0.1-0.15 \mathrm{~m}$ and height up to $20 \mathrm{~mm}$. Convolute laminations with asymmetrical folds are common in these beds. The upper portion is characterized by a structureless sandy mudstone up to $0.03 \mathrm{~m}$ thick (Fig. 6A).

Interpretation: The sedimentary features of this lithofacies indicate the deposition from combined flows. The lower portion laminations are interpreted as quasi-planar laminations of Arnott \& Southard (1990). The intermediate portion undulated laminations may be compared with small-scale anisotropic HCS and the overlying cross-laminations may be interpreted as combined-flow ripples (Nøttvedt \& Kreisa 1987, Cheel \& Leckie 1993, Dumas et al. 2005). The vertical transition of quasi-parallel lamination to anisotropic HCS, combined-flow ripples, and sandy mudstone indicate decreasing flow energy.

\section{Sandstone interbedded with sandy mudstone}

This lithofacies constitutes $24 \%$ of the thickness of the measured sections and consists of well-sorted, very fine-grained sandstone, which forms tabular beds, $0.02-0.14 \mathrm{~m}$, interbedded 


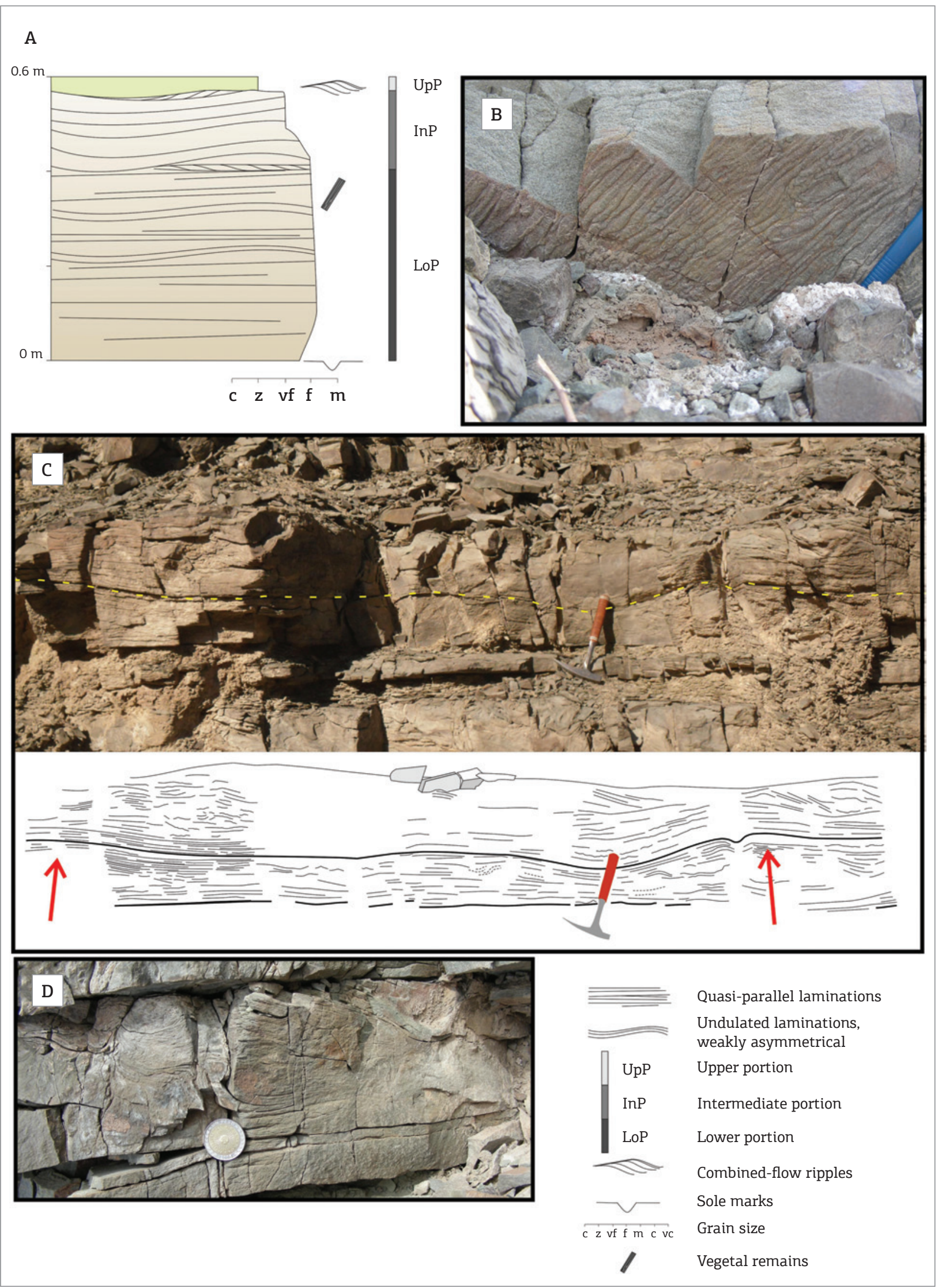

Figure 4. Sandstone with accretionary HCS. (A) Graphic sketch of lithofacies. (B) Longitudinal ridge and furrow sole marks. Pencil: $8 \mathrm{~mm}$ wide. (C) Arrows and dotted lines indicate the undulated top surface of the beds of this lithofacies. Hammer: 0.3 m. (D) Convolute laminations forming asymmetrical folds. Coin: 23 mm. 
with sandy mudstone, up to $0.45 \mathrm{~m}$ thick (Fig. 7A). Sandstone beds are constituted of up to three sets of low-angle, sigmoidal cross-laminations, which, on the top surface of the bed, correspond to ripples with weakly asymmetrical rounded crest (Fig. 7B). Isolated ripples (starved ripples) (Fig. 7C) and beds with convolute asymmetrical laminations are common.
Interpretation: Each sandstone/sandy mudstone constitutes a depositional event. The sandstone portion of this lithofacies is deposited from low-energy combined flows, and the sandy mudstone from settling at the end of the depositional event. Sandstone beds with one or more sets of cross-laminations indicate high sediment availability.

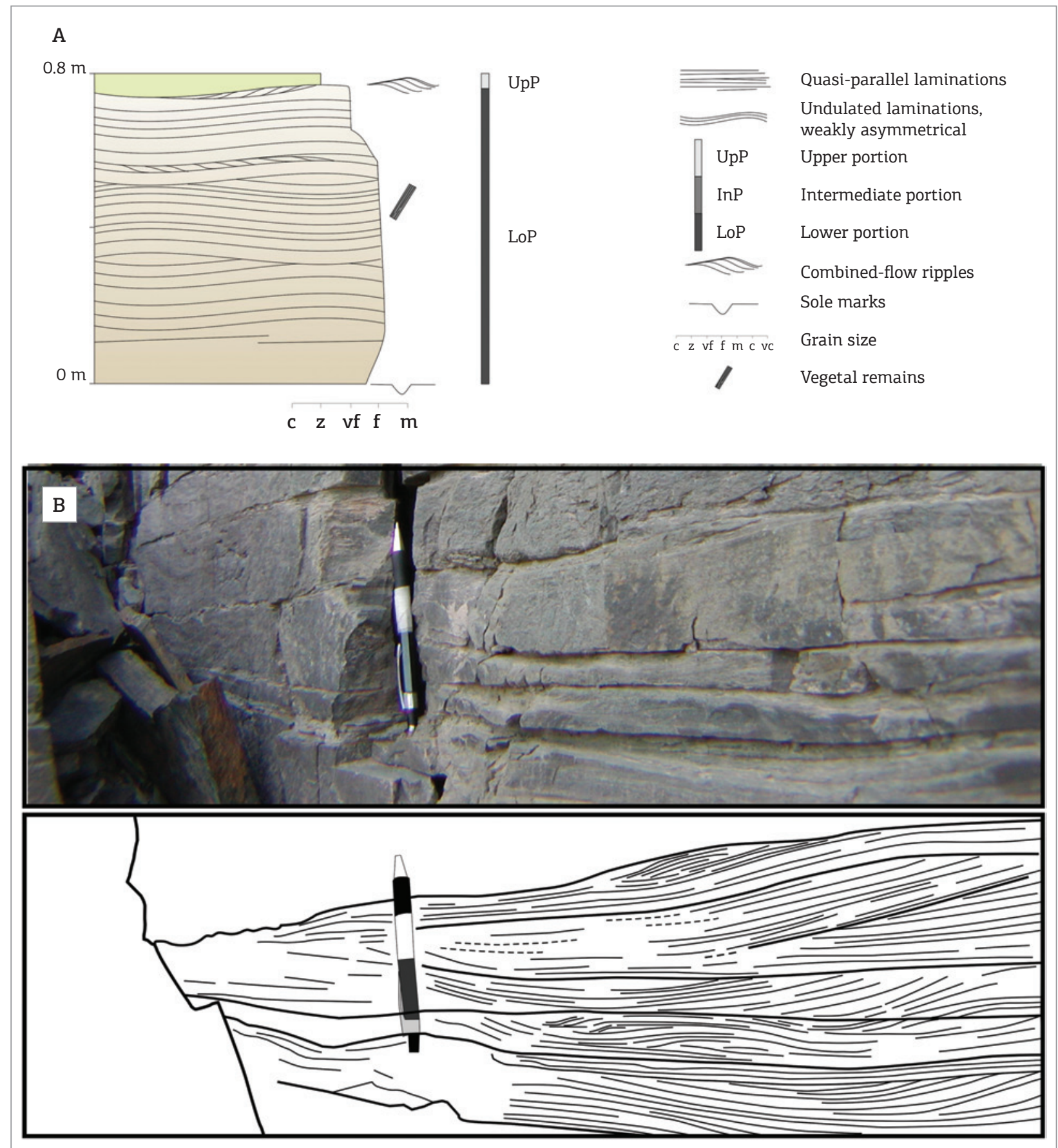

Figure 5. Sandstone with scour and drape HCS. (A) Graphic sketch of lithofacies. (B) Beds with predominant swales in the HCS structure. Pen: $0.12 \mathrm{~m}$. 


\section{Paleocurrent analysis}

The measurements of paleocurrent indicators were obtained from cross-laminations, groove marks, gutter casts, longitudinal ridge and furrows and wrinkle marks (Fig. 8). This analysis indicates sediment dispersal towards the west, with mean vector of $266.6^{\circ}$. These data correspond to the measurements achieved by Bonorino and Middleton (1976) and Bustos (1996).

\section{ICHNOFOSSILS OF PNF}

Fossil traces are frequently observed in PNF deposits. Individual beds present ichnofabric index (Pemberton et al. 1992) ranging from 2 to 3, which indicates that the amount of biogenic disturbance of sediment constitutes, respectively, from $0-10 \%$ to $10-40 \%$ of the deposits.

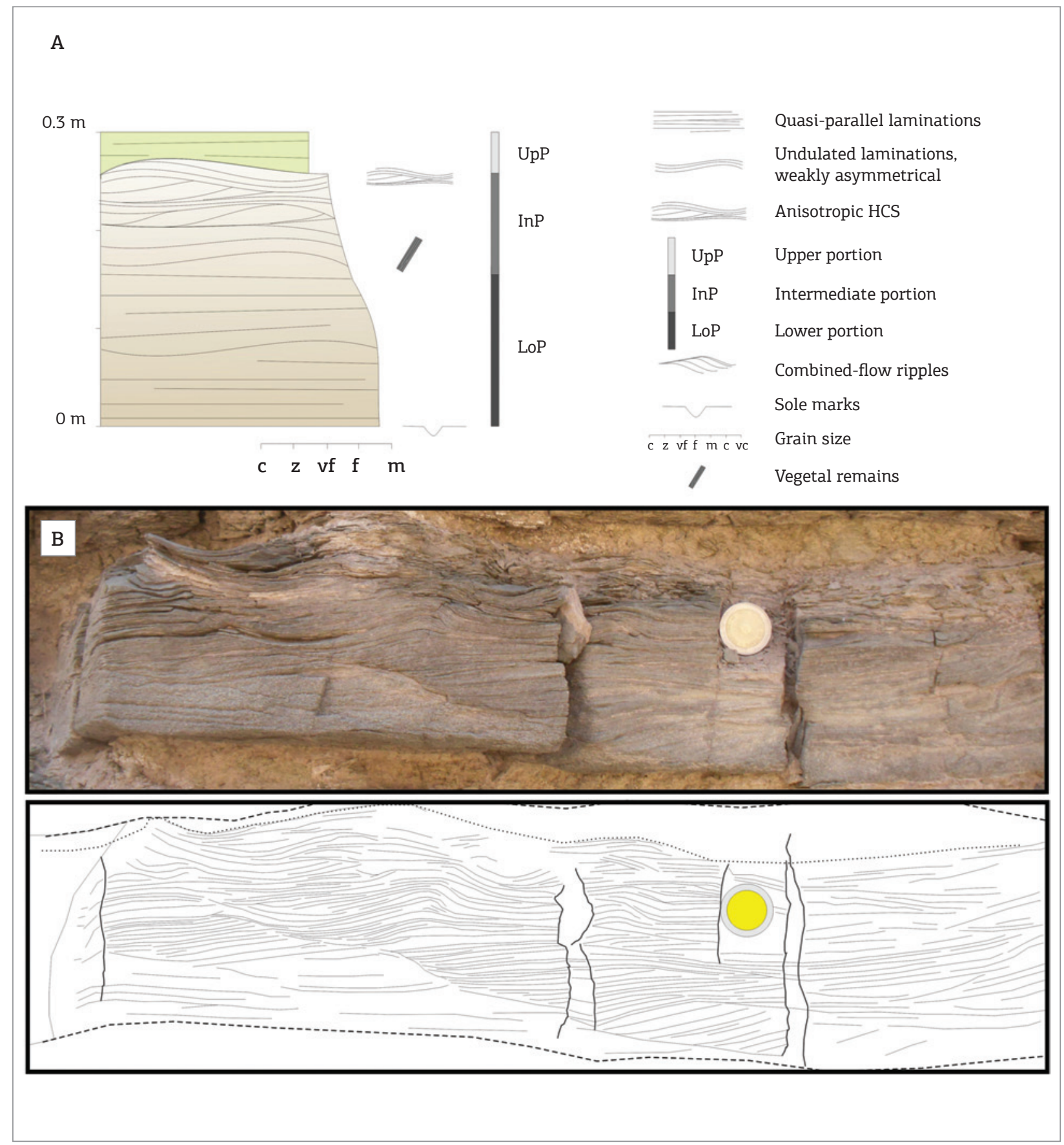

Figure 6. Sandstone with anisotropic HCS. (A) Graphic sketch of lithofacies. (B) Undulated laminations, weakly asymmetrical, which vertically or laterally have transition to cross-laminations produced by combined-flow ripples. Coin: $23 \mathrm{~mm}$. 


\section{Description of ichnofossils}

A total of 10 ichnogenera have been recognized in PNF. Ichnogenus Skolithos (Haldeman 1840) is mainly found at the top and in the center of sandstone beds, developing vertical to inclined unbranched cylindrical tubes (Fig. 9A). Traces with preserved transversal section are rare. In section, traces are rounded to elliptical shape with $2-15 \mathrm{~mm}$ of diameter. Locally, Skolithos traces present lines with that are $0.5-2.0 \mathrm{~mm}$ thick.

Ichnogenus Planolites (Nicholson 1873) and ichnogenus Paleophycus (Hall 1847) are mainly found in sandstone with HCS beds. They are composed of cylindrical unbranched horizontal to sub-horizontal traces, with shapes ranging from straight to curved. Traces are found as convex hyporelief or concave epirelief. In section, traces range from constantly cylindrical to slightly ovalized, with $1-20 \mathrm{~mm}$ in diameter. Planolites ichnites are lined and filled with material that is usually darker than the host rock, due to the high mud concentration (Fig. 9B). Paleophycus is less abundant, and different from Planolites traces, since they are unlined and have filling material similar to one in the host rock.

The ichnogenus Gordia (Emmons 1844) occurs mainly as positive hyporelief in the sandstone with HCS beds. They are composed of horizontal to sub-horizontal traces with sinuous, straight or spiral forms (Fig. 9C). Usually, traces are intersecting and generate a "false truncation" pattern. In section, traces are approximately cylindrical, with uniform diameters ranging from 1 to $15 \mathrm{~mm}$. No well-defined lining is observed, and filling material is similar to the host rock.

The ichnogenus Diplocraterion (Torell 1870) and the ichnogenus Arenicolites (Salter 1857) were found at the top of the sandstone with HCS, in sandstone with undulated laminae and in sandstone with anisotropic HCS beds. Diplocraterion occurs as cylindrical, vertical, "U" shaped burrows with $3-8 \mathrm{~mm}$ in diameter. Traces with the complete preserved section are rare, usually being found as two cylinders at the bed tops, conjugated or not (Fig. 9D). Spreiten is locally

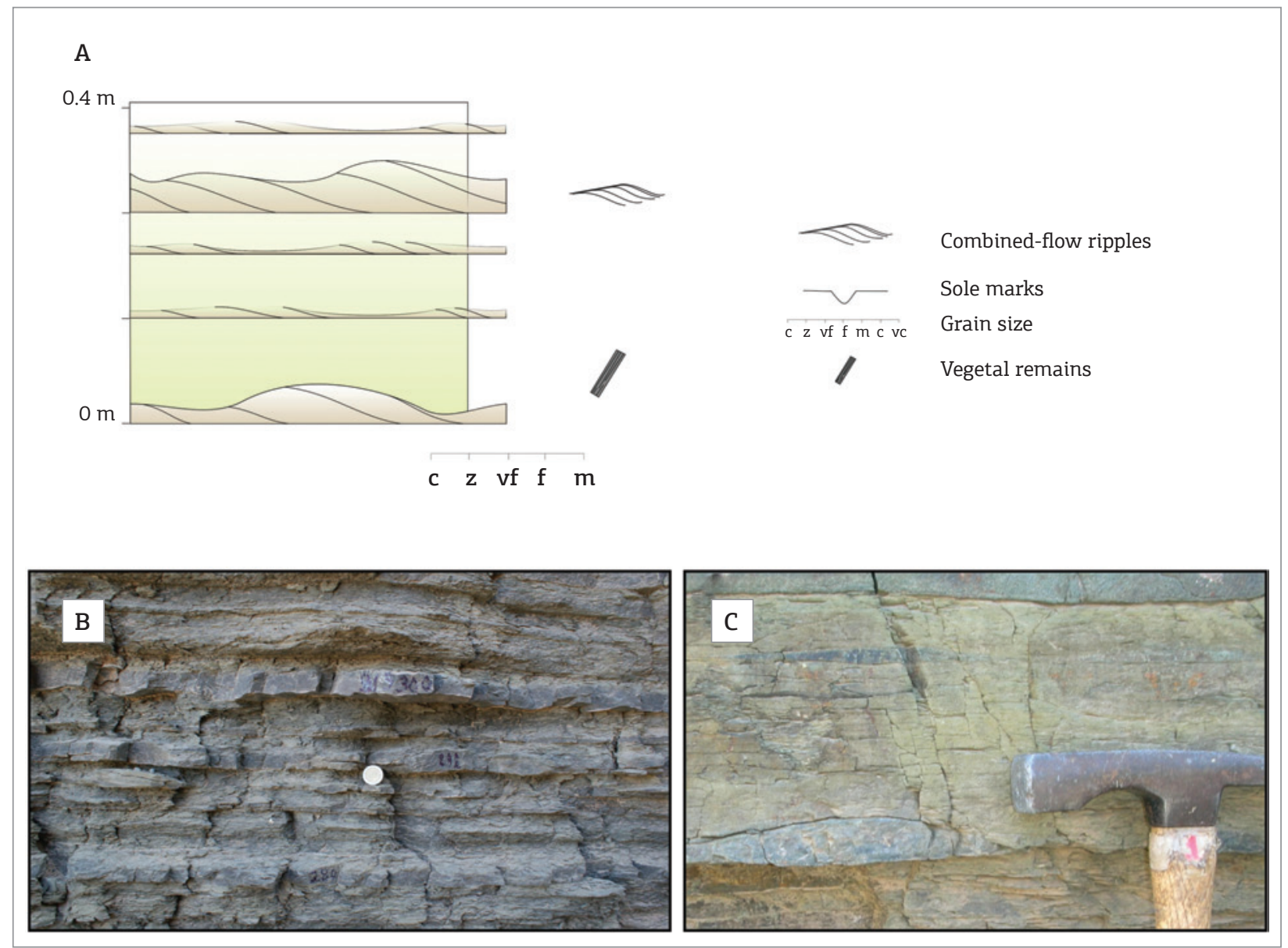

Figure 7. Sandstone interbedded with sandy mudstone. (A) Graphic sketch of lithofacies. (B) The beds of this lithofacies are constituted of weakly asymmetrical combined-flow ripples with rounded crest. (C) Isolates starved combined-flow ripples. Hammer's width: $35 \mathrm{~mm}$. 
well defined. Arenicolites traces are similar to Diplocraterion, however, they do not have spreiten.

The ichnogenus Chondrites (von Sternberg 1833) typically occurs in sandstone interbedded with sandy mudstone facies, with accessory traces with undulated laminae and sandstone with anisotropic HCS facies. Traces are formed by cylindrical to elliptical sub-vertical " $Y$ " shape branching $\left(20-90^{\circ}\right)$ tunnels with 2-10 mm in diameter (Figs. 10A and B). Ichnofossils are typically preserved as convex hyporelief, however, concave epirelief traces have also been registered. The filling material is usually dark, probably due to high organic matter or muddy content.

The only example of ichnogenus Rhizocorallium (Zenker 1836) was found as positive hyporelief at the bottom of the sandstone interbedded with sandy mudstone bed. The trace is curved, $15 \mathrm{~cm}$ long, $2.0-2.5 \mathrm{~cm}$ wide, and it has a sub-horizontal irregular lobate shape (Figs. 10C and 10D).

The ichnogenus Protopaleodictyon (Książkiewicz 1970) has rarely been found at the base of sandstone interbedded with sandy mudstone beds. This ichnite occurs as positive hyporelief, forming complex textural patterns, composed of irregular sinuous to highly angular meandering branched burrows (ranging from 30 to $120^{\circ}$ ), $1.5-3 \mathrm{~mm}$ thick (Figs. 10C and E).

Only one possible example of the ichnogenus Rusophycus (Hall 1852) was found at the base of a sandstone with HCS bed. This trace is $15 \mathrm{~mm}$ long, $10 \mathrm{~mm}$ wide and $3 \mathrm{~mm}$ high, and it has a lobate shape (Fig. 11A).

The ichnogenus Dictyodora (Weiss 1884) usually occurs in the finer grained portion of the sandstone facies interbedded with sandy mudstone, forming convex epirelief on the upper bedding plane surface. Dictyodora traces are formed by planar or gently inclined, cylindrical to ovalized sinusoidal burrows (Fig. 11B). Dictyodora traces are characterized by a complex tridimensional shape; traces are typically $2-4 \mathrm{~mm}$ wide in the basal portions with submilimetric width on the top. In section, traces have sinusoidal or spiral shapes, $20 \mathrm{~cm}$ long and $2.5 \mathrm{~cm}$ wide. Locally, ichnites with two orders of sinusoidal patterns are observed (Fig. 11C).

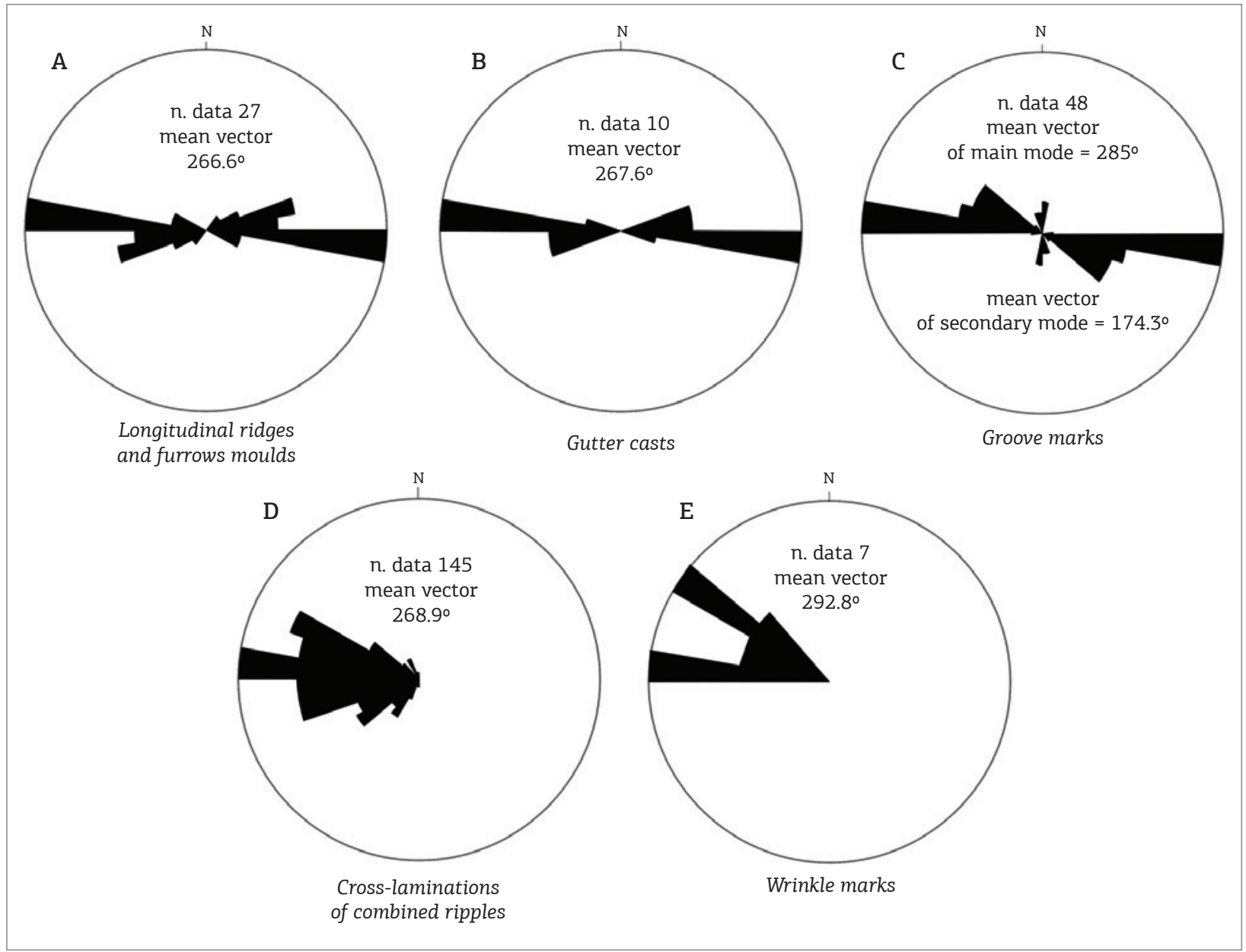

Figure 8. Rose diagrams for paleocurrent indicators. 


\section{Assemblages of ichnofossils}

PNF ichnites can be grouped into four main ichnofossil assemblages: Skolithos-Planolites, Skolithos-ArenicolitesDiplocraterion-Planolites-Gordia, Planolites-Gordia-Chondrite and Dictyodora-Chondrites-Protopaleodictyon-Rhizocorallium.

The Skolithos-Planolites assemblage is found in graded and thick sandstone bed lithofacies. This assemblage is characterized by the predominance of vertical to sub-vertical traces of Skolithos and not so abundant horizontal traces of the ichnogenus Planolites. The bioturbation disturbance grading of this assemblage is variable, although beds with this assemblage typically present ichnofabric index 2 .

The Skolithos-Arenicolites-Diplocraterion-Planolites-Gordia assemblage is typical of sandstone with HCS. In this assemblage, vertical and sub-vertical traces (Skolithos, Arenicolites and Diplocraterion Ichnogenera), as well as horizontal to sub-horizontal traces (Planolites and Gordia Ichnogenera) can be locally abundant, presenting ichnofabric index 2 and 3 . Well defined tiers are observed.
The Planolites-Gordia-Chondrites assemblage is observed only in sandstone with HCS. In this assemblage, horizontal to sub-horizontal ichnites (Planolites and Gordia ichnogenera) are predominant, while inclined to sub-vertical traces (Chondrites Ichnogenus) are less abundant. The possible Rusophycus ichnite occurs in association with this assemblage.

The Dictyodora-Chondrites-Protopaleodictyon-Rhizocollarium assemblage occurs in the sandstone interbedded with sandy mudstone in beds with ichnofabric index 2 and 3. Dictyodora horizontal traces and Chondrites inclined to sub-vertical traces are predominant in this assemblage.

Interpretation: the Skolithos-Planolites and the Skolithos-Arenicolites-Diplocraterion-Planolites-Gordia assemblages are interpreted as Skolithos ichnofacies (Frey \& Pemberton 1984). The presence of this ichnofacies and the relative abundance of ichnofossil structures indicate a well-oxygenated environment fed with organic matter. The predominance of vertical tunnels, related to suspension feeding organisms, suggests high abundance of organic particles
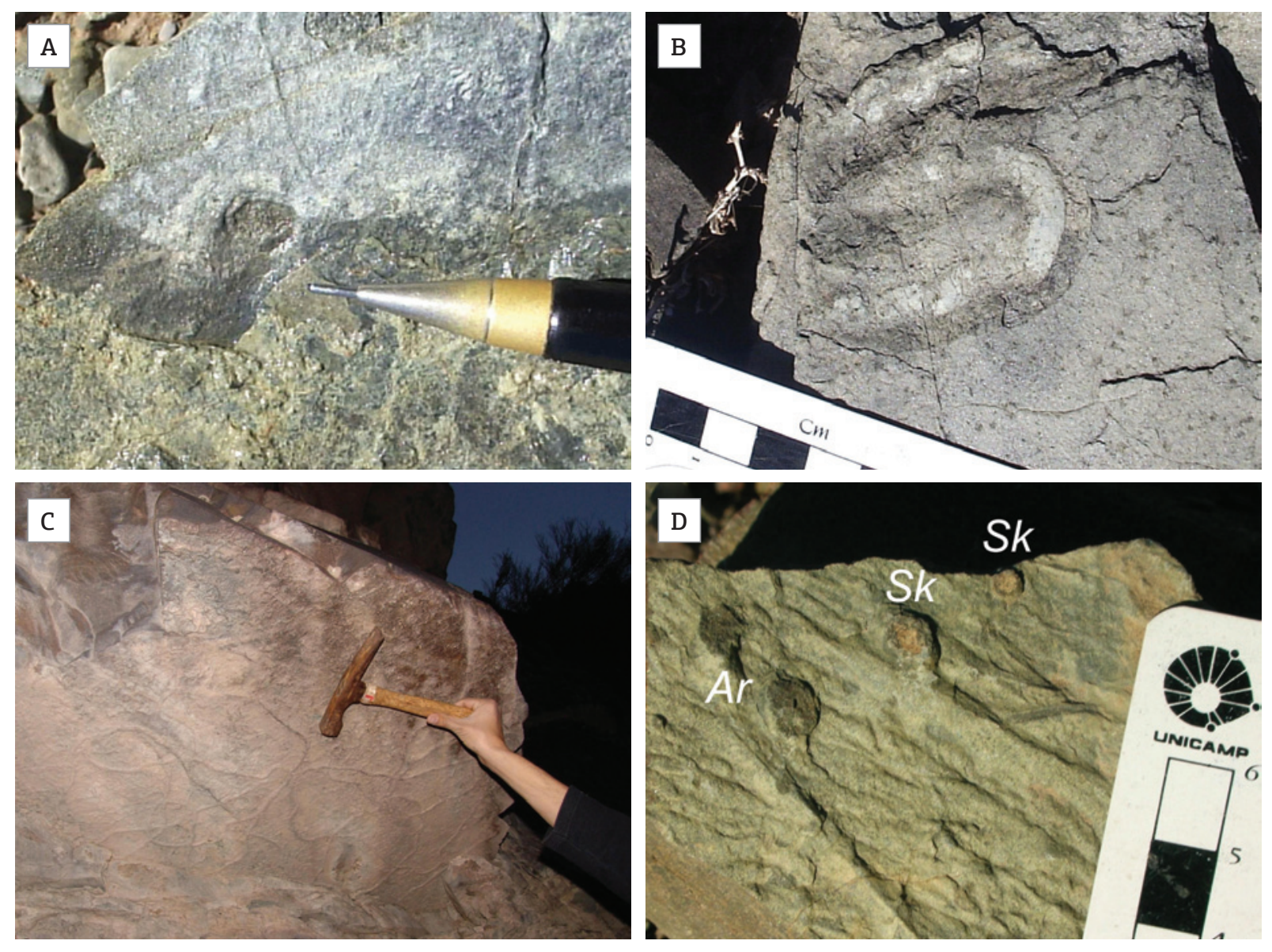

Figure 9. Ichnofossils of PNF. (A) Detailed section showing cylindrical Skolithos traces. Width of the pencil: $7 \mathrm{~mm}$. (B) Planolites filled with muddy sediment. (C) Gordia ichnites showing intersection of traces. Hammer: $0.28 \mathrm{~m}$. (D) Arenicolites (Ar) and Skolithos (Sk) traces. 

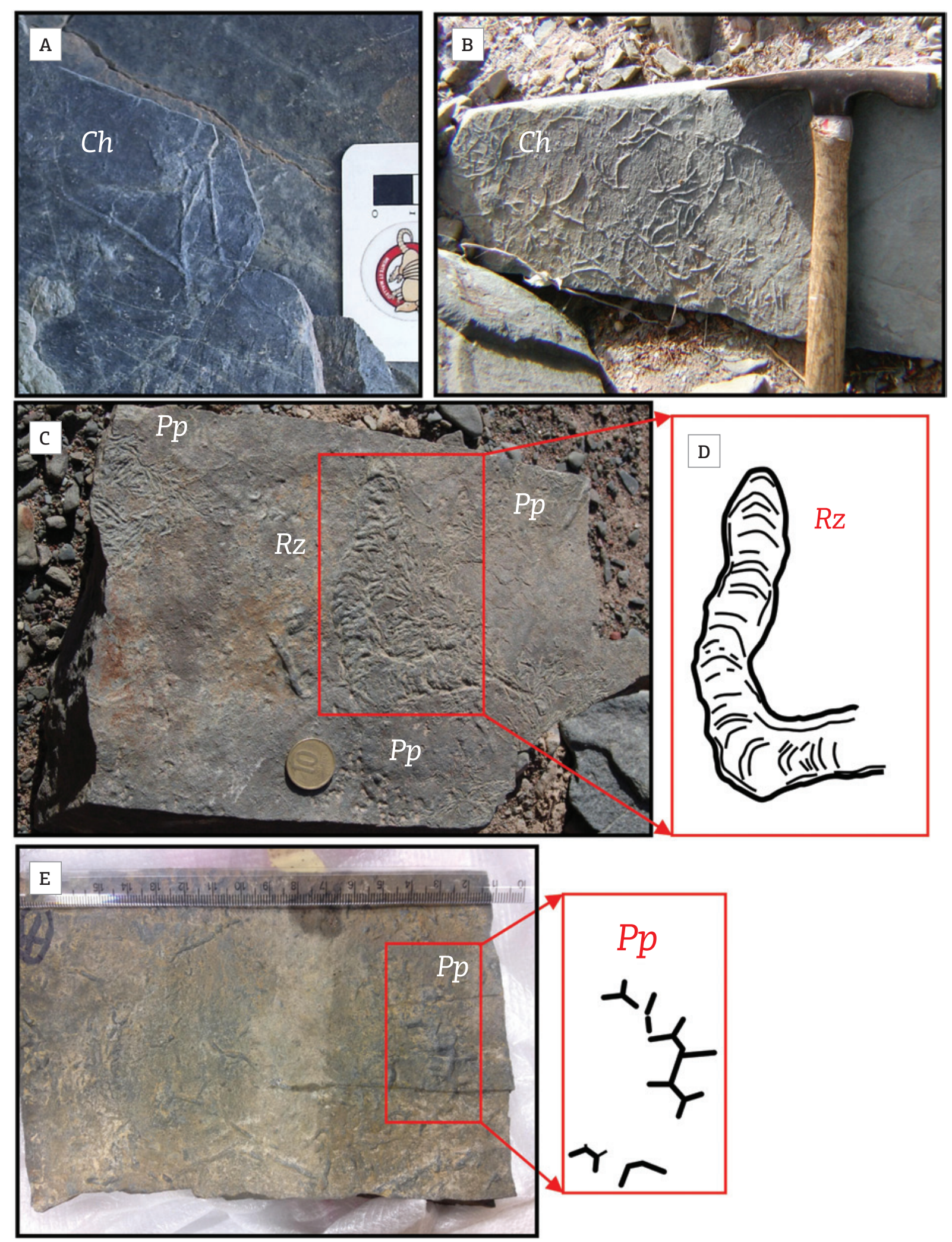

Figure 10. (A) and (B) Chondrites ichogenus (Ch) at the base surface of sandstone interbedded with sandy mudstone lithofacies. Hammer: $0.28 \mathrm{~m}$. (C) Rhizocollarium (Rz) and Protopaleodictyon (Pp) ichnogenera observed at the sole of interbedded sandstone beds with sandy mudstone lithofacies. Coin: $18 \mathrm{~mm}$. (D) Drawing showing a detail of Figure 10C. (E) Protopaleodictyon (Pp) at the bottom of sandstone interbedded with sandy mudstone lithofacies. 
kept suspended by waves and currents (Buatois \& Mángano 2011). The different density of the ichnites and the presence of low bioturbation index reveal a short colonization time window, which probably occurred right after high energy depositional events. These traces can be classified as opportunistic (r-selected) (Pemberton et al. 1992).

The Planolites-Gordia-Chondrites assemblage is characteristic of the Cruziana ichnofacies. Most of the traces in this ichnofacies are horizontal, with few inclined and vertical associated structures. This assemblage suggests the predominance of a mutable fauna, which is represented by the crawling (Repichnia) and feeding (Fodinichnia) traces. These traces indicate food availability in beds. The relative low bioturbation index, observed in most of the beds, suggests that the organisms lived in these beds just after the sedimentary event in a short colonization time window.

The Dictyodora-Chondrites-Protopaleodictyon-Rhizocollarium assemblage is interpreted as Nereites ichnofacies. The predominance of horizontal ichnites with complex structures (Dictyodora and Protopaleodictyon ichnogenera) indicates low
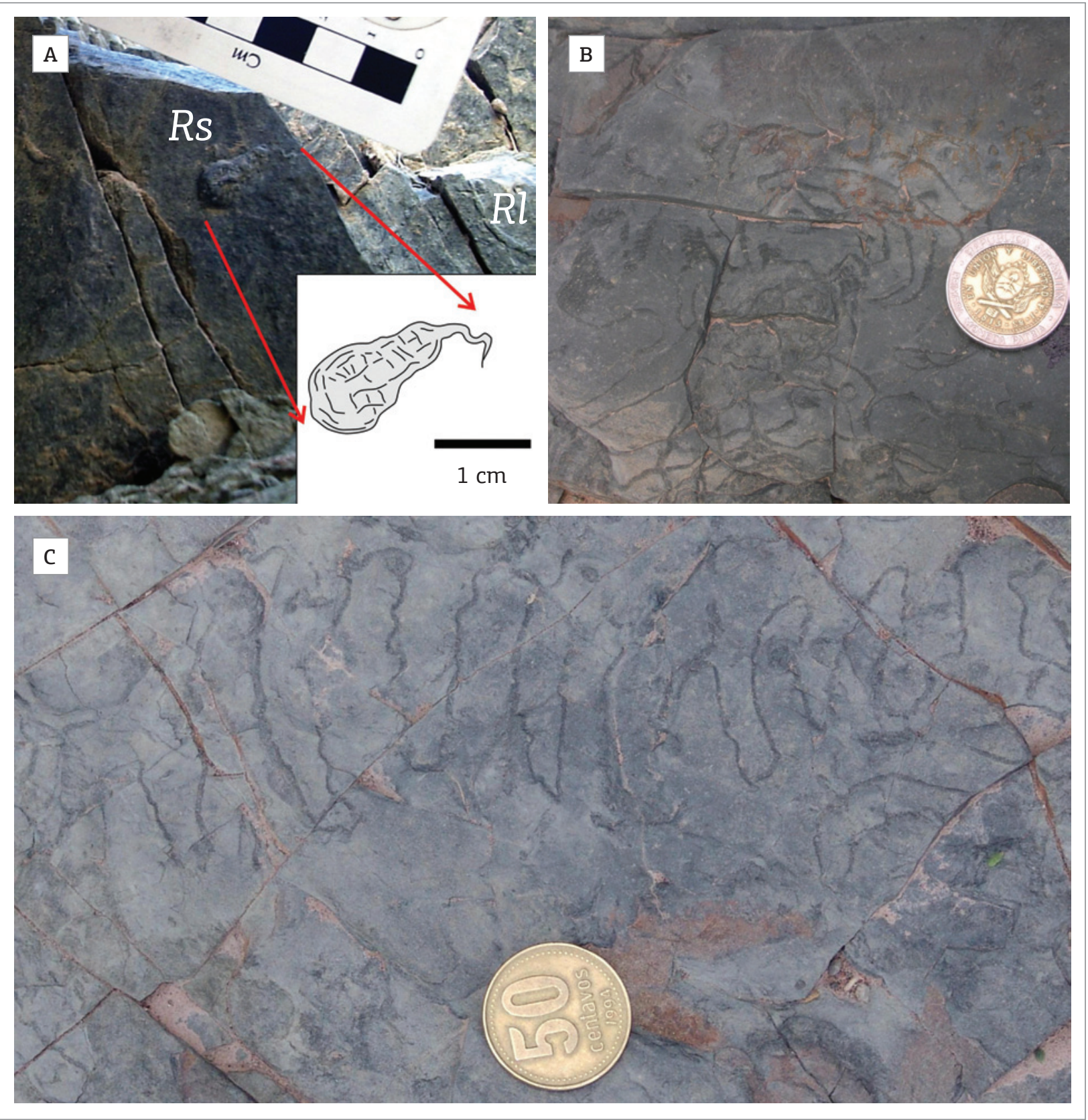

Figure 11. (A) Possible trace of Rusophycus ichogenus at the base surface of sandstone beds with HCS. (B) Meandering traces of ichnogenus Dictyodora. (C) Meandering Dictyodora ichnofossil showing two sinuosity orders. 
food availability, which is characteristic of low energy environments. The geometry of the Dictyodora, with spiral and sinusoidal patterns, is related to complex strategies developed to explore the food resources (Baucon \& Neto de Carvalho 2008).

In general, the Nereites ichnofacies is characterized by shallow-tier traces and high ichnodiversity (Seilacher 1977). The presence of complex structures is characteristic of special behaviours that need time to be developed. It is only possible under very stable environmental conditions in an overall low energy and well oxygenized setting (Buatois \& Mángano 2011). These ichnites can be interpreted as equilibrium traces ( $k$-selected-Pemberton et al. 1992). Equilibrium traces are typical of biological activity developed in still water settings, such as external platform or deep-water environments.

\section{ARCHITECTURAL ELEMENTS}

The described lithofacies were separated into three architectural elements: i) channelized sandstone; ii) tabular sandstone; and iii) tabular sandstone interbedded with mudstone (Tab. 1).

Channelized sandstone: This architectural element is composed of beds of graded and thick sandstone (Fig. 2B), constituting $5 \%$ of the entire measured succession. This element forms successions up to $21 \mathrm{~m}$ thick and $130 \mathrm{~m}$ wide perpendicularly to the paleocurrent directions. Sandstone beds were deposited in channelized forms from high energy hyperpycnal flows, whose behaviour was controlled by storms.

Tabular sandstone: this architectural element constitutes $65 \%$ of the thickness of the succession and is composed of the following lithofacies: sandstone with HCS, sandstone with anisotropic HCS, sandstone with undulated laminae, and sandstone interbedded with sandy mudstone. The first two lithofacies are common, while the other two are uncommon. This element is organized in tabular beds of mediumto very fine-grained sandstone, more than $70 \mathrm{~m}$ thick with lateral extension up to $2 \mathrm{~km}$ (Fig. 12A). Unconfined, high energy, combined, partially oscillatory flows were the depositional mechanisms of this architectural element.

Sandstone interbedded with mudstone: this element represents $30 \%$ of the thickness of the entire measured sedimentary succession. It is formed by thin beds of very fine-grained sandstone interbedded with sandy mudstone. Locally, sandstone with HCS may occur. This element is constituted of tabular bodies, 1 - $30 \mathrm{~m}$ thick, with more than $1 \mathrm{~km}$ lateral extension (Fig. 12A). At times, coarsening and thickening upwards sequences may be observed (Fig. 12B). Low-energy combined flows are possibly depositional mechanisms.

Table 1. Summary of architectural element features of the PNF

\begin{tabular}{|c|c|c|c|c|c|c|}
\hline 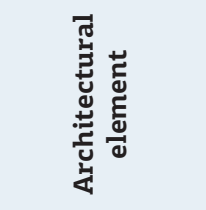 & 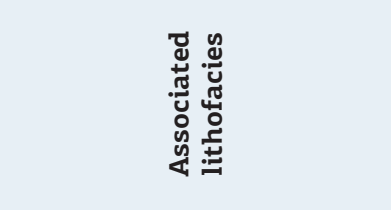 & 剀 & 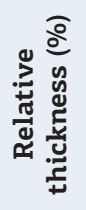 & 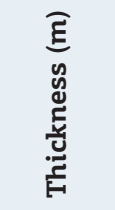 & 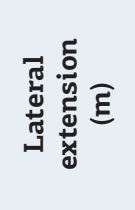 & 岕㮱 \\
\hline $\begin{array}{l}\text { Channelized } \\
\text { sandstone }\end{array}$ & $\begin{array}{c}\text { Graded and thick sandstone } \\
\text { (common). } \\
\text { Sandstone with HCS } \\
\text { (uncommon) }\end{array}$ & $\begin{array}{l}\text { Medium- or fine- } \\
\text { grained sandstone } \\
\text { beds with erosive } \\
\text { concave base and } \\
\text { interbedded with } \\
\text { sandy mudstone }\end{array}$ & 5 & 21 & $70-130$ & $\begin{array}{l}\text { Subaqueous channels } \\
\text { developed in front } \\
\text { of a delta system, } \\
\text { which are filled with } \\
\text { hyperpycnal flows } \\
\text { combined with storm } \\
\text { oscillatory flows }\end{array}$ \\
\hline $\begin{array}{c}\text { Tabular } \\
\text { sandstone }\end{array}$ & $\begin{array}{c}\begin{array}{c}\text { Sandstone with HCS } \\
\text { (common). }\end{array} \\
\text { Sandstone with anisotropic } \\
\text { HCS (common). Sandstone } \\
\text { with undulated laminae } \\
\text { (uncommon). } \\
\text { Sandstone interbedded with } \\
\text { sandy mudstone (uncommon). }\end{array}$ & $\begin{array}{l}\text { Tabular package of } \\
\text { tabular beds of } \\
\text { medium- to very fine- } \\
\text { grained sandstone, } \\
\text { with undulated top } \\
\text { surface }\end{array}$ & 65 & $10-70$ & 2000 & $\begin{array}{l}\text { Unconfined combined } \\
\text { flows of relatively } \\
\text { high energy }\end{array}$ \\
\hline $\begin{array}{c}\text { Tabular } \\
\text { sandstone } \\
\text { interbedded } \\
\text { with mudstone }\end{array}$ & $\begin{array}{l}\text { Sandstone interbedded with } \\
\text { sandy mudstone (common). } \\
\text { Sandstone with anisotropic } \\
\text { HCS (uncommon). }\end{array}$ & $\begin{array}{l}\text { Tabular package of } \\
\text { thin beds of very fine- } \\
\text { grained sandstone } \\
\text { interbedded with } \\
\text { mudstone }\end{array}$ & 30 & $0.5-10$ & 1000 & $\begin{array}{l}\text { Unconfined combined } \\
\text { flows of relatively } \\
\text { low energy }\end{array}$ \\
\hline
\end{tabular}




\section{DEPOSITIONAL MODEL}

The high concentration of vegetal remains and the low textural and compositional maturity of the sandstone suggest a nearby source of sediment with continental contribution, probably connected to a delta system (Nelson 1982, Pattison 2005, Myrow et al. 2008). The sedimentation of the PNF may have occurred in a prodelta environment, fed by unidirectional hyperpycnal flows, which charged a great quantity of sediments (oceanic floods) (Wheatcroft et al. 1997). Hyperpycnal flows are generated at the river mouth during catastrophic recurring events, which may last from $10^{2}$ to $10^{3}$ years (Mulder \& Syvitsky 1995). Due to the high transport capacity, these events are likely to have an important role in the sedimentary record.
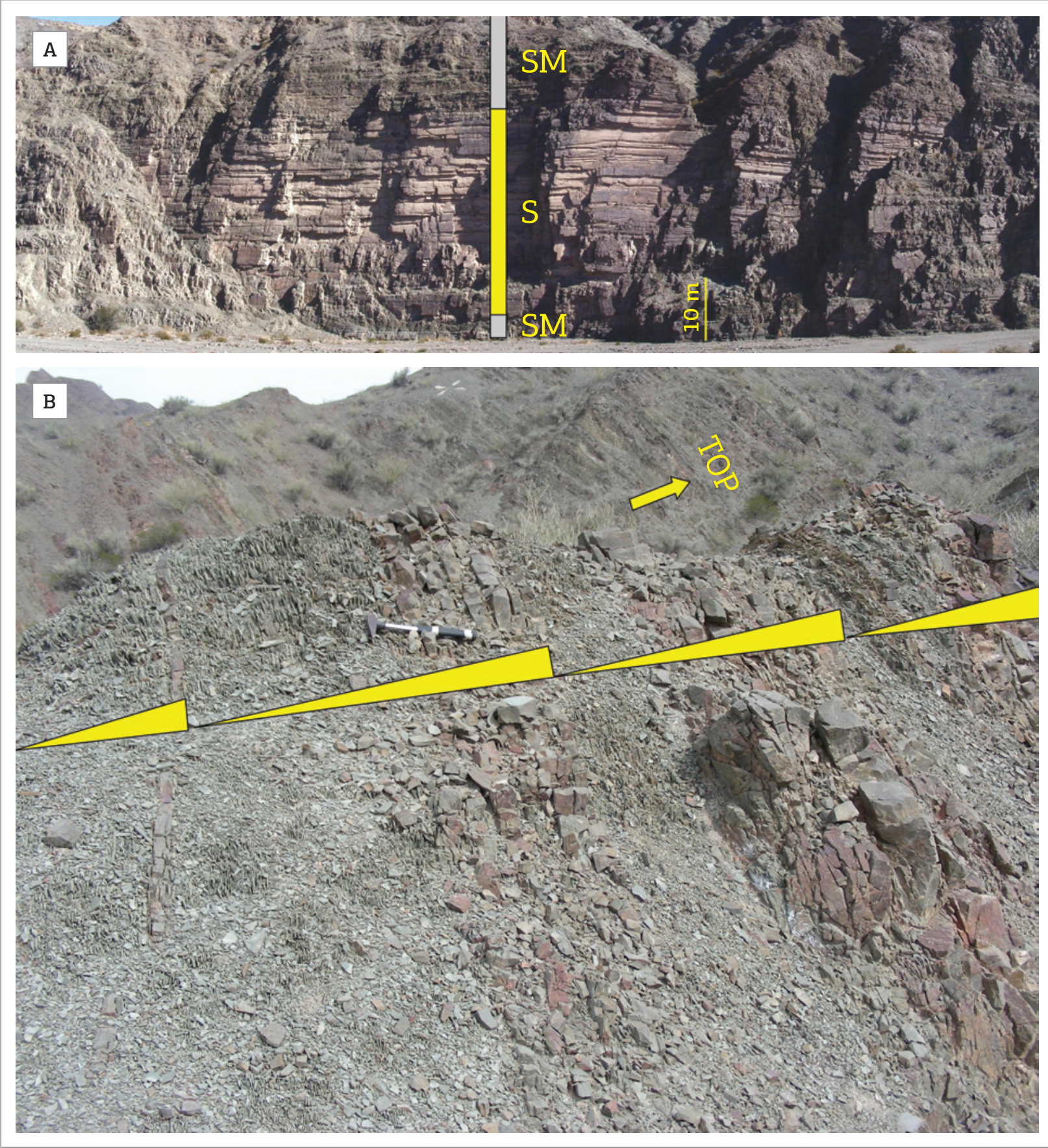

Figure 12. (A) Outcrop of tabular sandstone architectural element (S) alternated with tabular sandstone interbedded with mudstone architectural element (SM). (B) The tabular sandstone interbedded with mudstone architectural element locally displays a coarsening and thickening upward sequence. 
The lithofacies of PNF also have features that are connected to storm wave processes: quasi-planar laminations, accretionary HCS, anisotropic HCS and small combined-flow ripples, which suggest the contemporaneous effect of unidirectional and oscillatory flows into the transport and sedimentation processes (Harms et al. 1975, Arnott \& Southard 1990, Duke 1990, Myrow \& Southard 1991, Arnott 1993, Ito et al. 2001, Dumas et al. 2005, Yang et al. 2006, Lamb et al. 2008).
Based on these considerations, a facies tract model (Mutti 1992), which illustrates the lateral distribution of the architectural elements, may be built. This simple model can be explained by the decrease of energy in time and space of those depositional flows, which were the combination of hyperpycnal flows, generated at the mouth of a river, and contemporaneous storm waves, formed in the receiving water body (Fig. 13). At the proximal part, the channelized

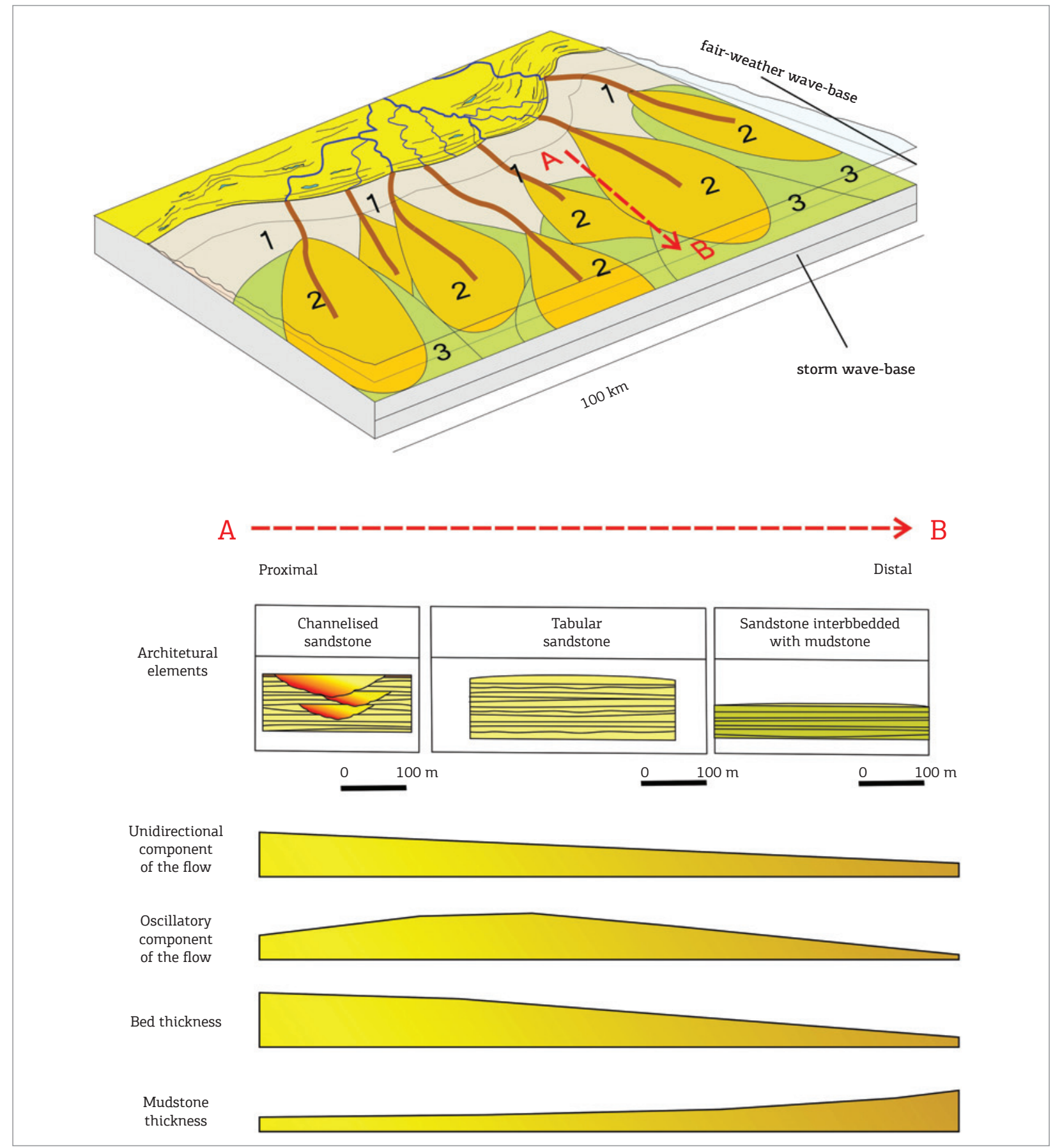

Figure 13. Simplified model of PNF sediment distribution. Architectural elements: 1 (channelized sandstone.); 2 (tabular sandstone); 3 (sandstone interbedded with mudstone). 
sandstone element records the sedimentation of the thickest and coarsest deposits (Fig. 13). The intermediate part is dominated by tabular sandstone beds, which have smaller grains and less thickness than the previous element (Fig. 13). The distal part is characterized by the thin interbedding of very fine-grained sandstone and mudstone. The beds of this architectural element (sandstone interbedded with mudstone) testify the low depositional energy of the system (Fig. 13).

The ichnofossil assemblages of PNF, which are attributed to the Skolithos, Cruziana and Nereites ichnofacies, support the hypothesis that PNF deposits were developed in a sedimentary environment below the wave-base level, in which hyperpycnal flows, associated to storm events, transported great amounts of sediments and nutrients.

The interchange between Skolithos, Cruziana and Nereites ichnofacies indicates cyclic variations of the energetic characteristics of the depositional environment, which is related to the intercalation between storm events and calm periods. Ichnites of Skolithos and Cruziana ichnofacies are related to high energy storm events, which are also responsible for the development of channelized sandstone and tabular sandstone architectural element deposits (Fig. 14).

On the other hand, Nereites ichnofacies is composed of traces developed under still conditions, which were developed after storm events, with the settlement of muddy sediment and organic matter. This ichnofacies is typical of tabular sandstone interbedded with mudstone architectural element (Fig. 14). Although the Nereites ichnofacies is considered to be a typical example of deep-water systems (Seilacher 1963, 1967), Olivero et al. (2010) and Uchman et al. (2004) observed that traces of these ichnofacies may occur in shallower environments, when there is low energy and well oxygenized stable environmental conditions (Buatois \& Mángano 2011). The presence of Nereites ichnofacies in the

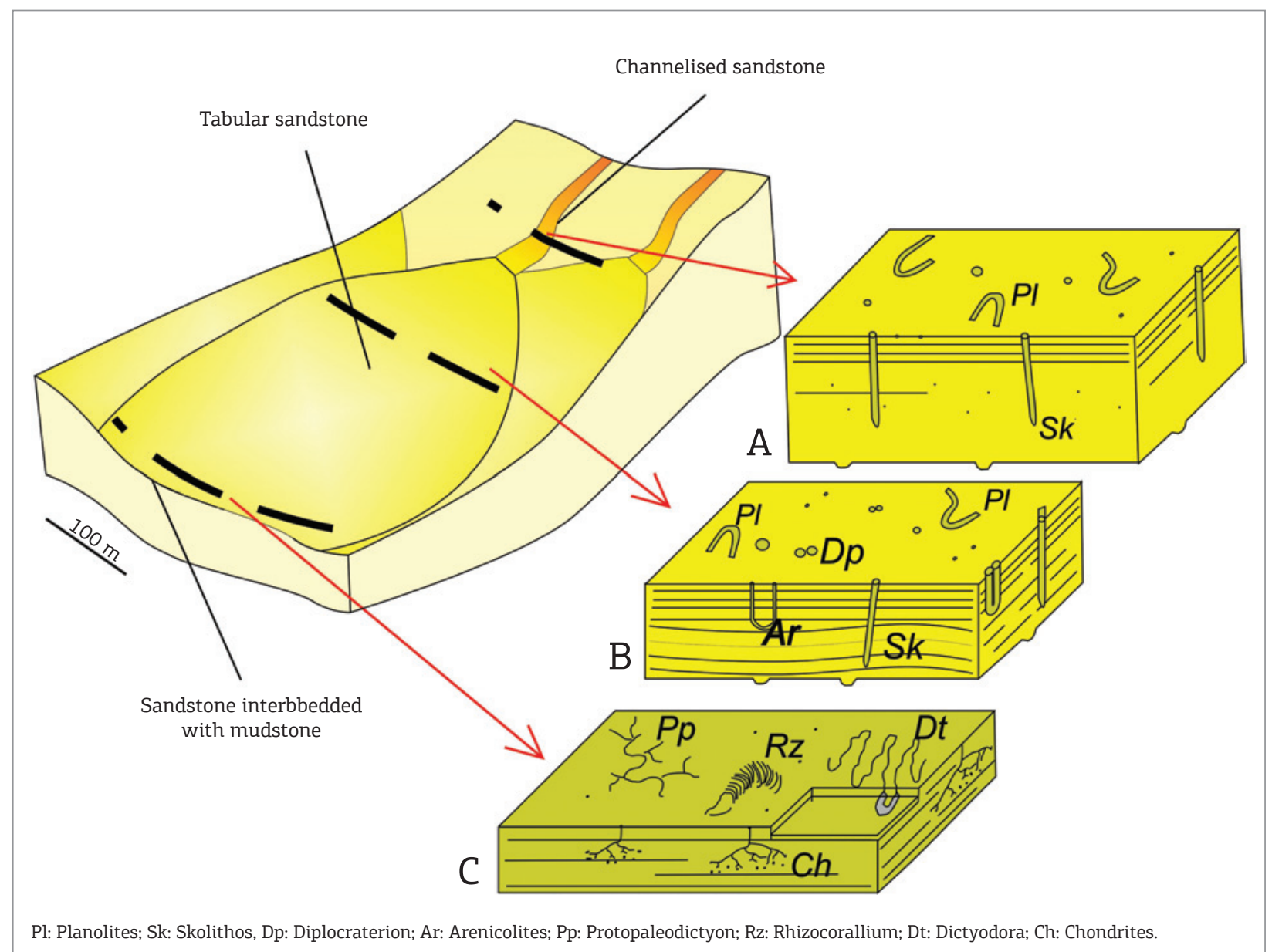

Figure 14. Skolithos-Planolites assemblage ichnites (Skolithos icnofacies) are characteristic of the channelized sandstone architectural element, located in the most proximal areas (A). The Skolithos-Arenicolites-DiplocraterionPlanolites-Gordia (Skolithos ichnofacies) and Planolites-Gordia-Chondrites (Cruziana ichnofacies) assemblages are typical of the tabular sandstone architectural element (B). The Dictyodora-Chondrites-ProtopaleodictyonRhizocorallium assemblage (Nereites ichnofacies) is characteristic of the tabular sandstone interbedded with mudstone architectural element deposits (C). 
tabular sandstone interbedded with mudstone architectural element indicates that this element has been deposited in a low energy environment, with few food resources and low sedimentation rates. This environment was characterized by long gaps of time between different depositional events, which allowed the proliferation of distinct ichnofauna and high specialized organisms.

\section{CONCLUSIONS}

The PNF sedimentary succession has been reinterpreted as a prodelta system dominated by hyperpycnal flows associated to storm waves. PNF beds are mainly constituted by litharenite or sublitharenite, characterized by low textural and mineralogical maturity, suggesting the proximity of the continental source of sediment. The described lithofacies have been deposited by the combination of oscillatory and unidirectional flows with variable energy, generated by storm waves and hyperpycnal flows, respectively.

The distribution of ichnofossil assemblage in the lithofacies, associated to Skolithos, Cruziana and Nereites ichnofacies, indicate constant variations of the paleoenvironmental conditions. During calm periods, in between depositional events, specialized organisms of Nereites ichnofacies proliferated. Just after the high energy depositional flows, the increased oxygen concentration and food resources allowed the colonization of opportunistic organisms (Skolithos and Cruziana ichnofacies).

Lithofacies have been separated into three architectural elements (channelized sandstone, tabular sandstone and sandstone interbedded with mudstone), which, according to a model based on grain size, thickness and energy of the depositional flows, were distributed in this order from coast to offshore.

\section{ACKNOWLEDGEMENTS}

The authors would like to thank Fapesp (Project 2006/00525-2) and CNPq (Project 473356/2007-4) for financing this study. We are grateful to Arturo Curatola and Andrés for their great hospitality during the field work in Estância Don Carmelo. Two anonymous referees and the Associate Editor of BJG (Claudio Riccomini) were very helpful by contributing with their observations to the review of the manuscript. Finally, we are indebted to the English reviser of the Brazilian Journal of Geology.

\section{REFERENCES}

Allen J.R.L. 1984. Sedimentary Structures: Their Character and Physical Basis. Amsterdam, Elsevier. 663 p.

Arnott R.W.C. 1993. Quasi-planar-laminated sandstone beds of the Lower Cretaceous Bootlegger Member, north-central Montana: evidence of combined-flow sedimentation. Journal of Sedimentary Petrology, 63:488-494

Arnott R.W.C. \& Southard J.B. 1990. Exploratory flow-duct experiments on combined flow bed configurations, and some implications for interpreting storm-event stratification. Journal of Sedimentary Petrology, 60:211-219.

Basilici G., De Luca P.H.V., Oliveira E.P. 2012a. A depositional model for a wave-dominated open-coast tidal flat, based on analyses of the Cambrian-Ordovician Lagarto and Palmares formations, northeastern Brazil. Sedimentology, 59:1613-1639.

Basilici G., De Luca P.H.V., Poiré D.G. 2012b. Hummocky crossstratification-like structures and combined-flow ripples in the Punta Negra Formation (Lower-Middle Devonian, Argentine Precordillera): A turbiditic deep-water or storm-dominated prodelta inner-shelf system? Sedimentary Geology, 267-268:73-92

Baucon A. \& Neto De Carvalho C. 2008. From the river to the sea: Pramollo, a new ichnolagerstätte from the Carnic Alps (Carboniferous, Italy-Austria). Studi Trentini di Scienze Naturali Acta Geologica, 83:87-114.

Bhattacharya H.N. \& Bhattacharya B. 2005. Storm event beds in a Paleoproterozoic Rift Basin, Aravalli Supergroup, Rajasthan, India. Gondwana Research, 8:231-239
Bhattacharya H.N., Bhattacharya B., Chakraborty I., Chakraborty A. 2004. Sole marks in storm event beds in the Permo-Carboniferous Talchir Formation, Raniganj Basin, India. Sedimentary Geology, 166:209-222.

Brenchley P.J. \& Newall G. 1982. Storm-influenced inner-shelf sand lobes in the Caradoc (Ordovician) of Shropshire, England. Journal of Sedimentary Petrology, 52:1257-1269.

Bridge J.S. 1993. Description and interpretation of fluvial deposits: a critical perspective. Sedimentology, 40:801-810.

Buatois L. \& Mángano, M.G. (eds) 2011. Ichnology: OrganismSubstrate Interactions in Space and Time. Cambridge, Cambridge University Press, 358 p.

Bustos U. \& Astini R.A. 1997. Formación Punta Negra: análisis secuencial y evolución de la Cuenca Devónica Precordillerana. Revista de la Asociación Geológica Argentina, 4:97-109.

Bustos U. 1996. Modelo sedimentário alternativo para el Devónico de la Precordillera central sanjuanina: Formación Punta Negra. Revista de la Asociación Geológica Argentina, 3:17-30.

Cheel R.J. \& Leckie D.A. 1993. Hummocky cross-stratification. In: Wright V.P. (ed.) Sedimentology Review. Oxford, Blackwell Science, p. 103-122.

Craft R.J. \& Bridge J.S. 1987. Shallow-marine sedimentary processes in the Late Devonian Catskill Sea, New York State. Geological Society of America Bulletin, 98:338-355.

Cuerda A.J., Arrondo O., Morel E., Spalletti L.A. 1990. Procesos de continentalizacion en el Devónico de la Precordillera. Revista del musel de La Plata, 10:185-195. 
Dott R.H. \& Bourgeois, J. 1982. Hummocky stratification: Significance of its variable bedding sequences. Geological Society of America Bulletin, 93:663-680

Duke W.L. 1990. Geostrophic circulation or shallow marine turbidity currents? The dilemma of paleoflow patterns in storm-influenced prograding shoreline systems. Journal of Sedimentary Petrology, 60:870-883

Dumas S., Arnott R.W.C., Southard J.B. 2005. Experiments on oscillatory-flow and combined-flow bedforms: implications for interpreting parts of the shallow marine rock record. Journal of Sedimentary Research, 75:501-513.

Dzulynski S. 1965. New data on experimental production of sedimentary structures. Journal of Sedimentary Petrology, 35:196-212.

Edwards D., Poiré D.G., Morel E.M., Cingolani C.A. 2009. Plant assemblages from SW Gondwana: further evidence for high-latitude vegetation in the Devonian of Argentina. In: Bassett M.G. (ed.) Early Palaeozoic peri-Gondwana terranes: new insights from tectonics and biogeography. Geological Society of London Special Publications, London. 325:233-255.

Emmons E. 1844. The Taconic System: Based on observations in New York Massachusetts, Maine, Vermont and Rhode Island. Albany, Caroll and Cook. 68 p.

Figueiredo A.G. 1980. Response of water column to strong wind forcing, southern Brazil inner shelf: implications for sand ridge formation. Marine Geology, 35:367-376.

Frey R.W. \& Pemberton S.G. 1984. Trace fossil facies models. In: Walker R.G. (ed.) Facies Models (2nd ed.). Geoscience Canada, Reprint Series I, p. 189-207.

Gonzales Bonorino G. \& Middleton G.V. 1976. A Devonian submarine fan in western Argentina. Journal of Sedimentary Petrology, 46:56-69.

Haldeman, S.S. 1840. Supplement to number one of a monograph of the Limniades and other freshwater bivalve shells of the apparently new animals in different classes, and names and characters of the subgenera in Paludina and Anculosa, Philadelphia. Philadelphia. 1:1-3.

Hall J. 1847. Palæontology of New-York, Vol I. Albany, C. van Benthuysen. 338 p.

Hall J. 1852. Paleontology of New York, Vol. II. Albany, C. van Benthuysen. $362 \mathrm{p}$

Hamblin A.P. \& Walker, R.G. 1979. Storm-dominated shallow marine deposits: the Fernie- Kootenany (Jurassic) transition, southern Rocky Mountains. Canadian Journal of Earth Science, 16:1673-1690.

Harms J.C., Southard J.B., Spearing D.R., Walker R.G. 1975. Depositional environments as interpreted from primary sedimentary structures and stratification sequences. SEPM Short Course, 2, Calgary, Society of Economic Paleontologists and Mineralogists, $161 \mathrm{p}$.

Higgs R. 1991. The Bude Formation (Lower Westphalian), SW England: siliciclastic shelf sedimentation in a large equatorial lake. Sedimentology, 38:445-469.

Ito M., Ishigaki A., Nishikawa T., Saito T. 2001. Temporal variation in the wavelength of hummocky cross-stratification: Implications for storm intensity through Mesozoic and Cenozoic. Geological Society of America, 29:87-89.

Keller M. 1999. Argentine Precordillera: sedimentary and plate tectonic history of a Laurentian crustal fragment in South America. Geological Society of America Special Paper, 341:1-131.

Keller M., Buggisch W., Lehnert O. 1998. The stratigraphical record of the Argentine Precordillera and its plate-tectonic background. In: Pankhurst R.J. \& Rapela C.W. (eds.) The Proto-Andean Margin of Gondwana. London, Geological Society of London Special Publication. 142 p.
Książkiewicz M. 1970. Trace fossils in the flysch of the Polish carpathians. Palaeontologica Polonica, 36:1-208.

Lamb M.P., Myrow P.M., Lukens C., Houck K., Strauss J., 2008. Deposits from waveinfluenced turbidity currents: Pennsylvanian Minturn Formation, Colorado, U.S.A. Journal of Sedimentary Research, 78:480-498.

Leckie D.A. \& Krystinik L.F. 1989. Is there evidence for geostrophic currents preserved in the sedimentary record of inner to middleshelf deposits? Journal of Sedimentary Petrology, 59:862-870.

Leckie D.A. \& Walker R.G. 1982. Storm-dominated and tidedominated shorelines in Cretaceous Moosebar Lower Gates Interval Outcrop equivalents of deep basin gas trap in western Canada Reply. American Association of Petroleum Geologists Bulletin, 66:2683-2684.

Massuda F. \& Yokokawa M. 1993. Combined flow ripple profiles: a preliminary note. Journal of Sedimentary Society of Japan, 38:107-111.

Miall A.D. 1985. Architectural-element analysis: a new method of facies analysis applied to fluvial deposits. Earth-Science Reviews, 22:261-308.

Molina J.M., Alfaro P., Moretti M., Soria J.M. 1998. Soft-sediment deformation structures induced by cyclic stress of storm waves in tempestites (Miocene, Guadalquivir Basin, Spain). Terra Nova, 10:145-150.

Mulder T. \& Syvitski J.P.M. 1995. Turbidity currents generated at river mouths during exceptional discharges to the world oceans. Journal of Geology, 103:285-299.

Mutti E. 1992. Turbidite sandstone. Milano, Agip Spa. 276 p.

Myrow P.M. 1992. Bypass-zone Tempestite facies model and proximality trends for an ancient muddy shoreline and shelf. Journal of Sedimentary Petrology, 62:99-115.

Myrow P.M. \& Southard J.B. 1991. Combined-flow model for vertical stratification sequences in shallow marine storm-deposited beds. Journal of Sedimentary Petrology, 61:202-210.

Myrow P.M. \& Southard J.B. 1996. Tempestite deposition. Journal of Sedimentary Research, 66:875-887.

Myrow P.M., Woodward F., Goodge J.W. 2002. Wave-modified turbidites: combined-flow shoreline and shelf deposits. Cambrian, Antartica. Journal of Sedimentary Research, 72:641-656.

Myrow P.M., Lukens C., Lamb M.P., Houck K., Strauss J. 2008. Dynamics of a transgressive prodeltaic system: implications for geography and climate within a Pennsylvanian intracratonic basin, Colorado, U.S.A. Journal of Sedimentary Research, 78:512-528.

Nelson C.H. 1982. Modern shallow-water graded sand layers from storm surges, Bering shelf: a mimic of Bouma sequences and turbiditic systems. Journal of Sedimentary Petrology, 52:536-545.

Nicholson H.A. 1873. Contributions to the study of the errant Annelids of the older Paleozoic rocks. Proceedings of the Royal Society of London, 21:288-290.

Nøttvedt A., \& Kreisa R.D. 1987. Model for combined-flow origin of hummocky crossstratification. Geology, 15:357-361.

Olivero E., Lopez C.M.,, Malumián N., Torres Carbonell P.J. 2010. Eocene Graphoglyptids from shallow-marine, high energy, organicrich, and bioturbated turbidites, Fuegian Andes, Argentina. Acta Geologica Polonica, 60:77-91.

Parker G. 1982, Conditions for the catastrophically erosive turbidity currents. Marine Geology, 46:307-327.

Pattison S.A.J. 2005. Storm-influenced prodelta turbidite complex in the lower Kenilworth Member at Hatch Mesa, Book Cliffs, Utah, USA: implications for shallow marine facies models. Journal of Sedimentary Research, 75:420-439. 
Pattison S.A.J., Ainsworth R.B., Hoffman, T.A. 2007. Evidence of across-shelf transport of fine-grained sediments: turbidite-filled shelf channels in the Campanian Aberdeen Member, Book Cliffs, Utah, USA. Sedimentology, 54:1033-1063.

Pemberton S.G., MacEachern J.A., Ranger M.J. 1992. Ichnology and event stratigraphy: the use of trace fossils in recognizing tempestitos. In: Pemberton S.G. (ed). Applications of ichnology to petroleum exploration, a core workshop. SEPM Core Work-shop, p. 85-117.

Poiré D.G. \& Morel E.M. 1996. Procesos sedimentarios vinculados a la depositación de niveles con plantas en secuencias Siluro-Devónicas de la Precordillera, Argentina. In: Actas VI Reunión Argentina de Sedimentología, VI, p. 205-210.

Ramos V.A. \& Vujovich, G.I. 2000. Hoja Geológica 3169 - IV: San Juan. Provincia San Juan. Escala 1:250.000. Texto explicativo. Buenos Aires, Programa nacional de Cartas Geológicas de La Republica Argentina, Servicio Geológico Minero Argentino.

Rapela C.W., Pankhurst R. J., Casquet C., Baldo E., Savedra J., Galindo C. 1998. Early evolution of the proto-Andean os South América. Geology, 26:707-710.

Salter J.W. 1857. On annelide-burrows and surface markings from the Cambrian rocks of the Longmynd. Geological Society of London Quaterly Journal, 13:199-206.

Seilacher A. 1963. Lebensspuren und Salinitats fazies-Symposium zur Unterschiedung mariner und nicht-mariner Sediment.Dusseldorf, 1962. Fort schr. in der Geol. von Rheinl. und West-falen, 10:81-94.

Seilacher A.1967. Bathymetry of trace fossils. Marine Geology, 5:413-428

Seilacher A. 1977. Pattern analysis of Paleodictyon and related trace fossils. In: Crimes T.P. \& Harper J.C. (eds), Trace Fossil 2, Geological Journal, Special Issue, 9:289-334.

Snedden J.W. \& Swift D.J.P. 1991. Is there evidence for geostrophic currents preserved in the sedimentary record of inner- to middleshelf deposits?-Discussion. Journal of Sedimentary Petrology, 6:148-151

Snedden J.W., Nummedal D., Amos A.F. 1988. Storm- and fairweather combined flow on the central Texas continental shelf. Journal of Sedimentary Petrology, 58:580-595.

Swift D.J.P. 1985. Response of the shelf floor to flow. In: Tillman R.W., Swift D.J.P., Walker R.G. (eds). Shelf Sands and Sandstone Reservoirs, Tulsa, Society of Economic Paleontologists and Mineralogists, p.135-241
Swift D.J.P., Gregory H., Vincent C.E. 1986. Fluid processes and seafloor response on a modern storm-dominated shelf: middle Atlantic Shelf of North America. Part 1: The storm current regime. In: Knight R.J., \& McLean J.R. (eds.) Shelf Sands and Sandstones. Canadian Society of Petroleum Geologists, p. 99-119.

Thomas W.A. \& Astini R.A. 2003. Ordovician accretion of the Argentine Precordillera terrane to Gondwana: a review. Journal of South American Earth Sciences, 16:67-79.

Torell O. 1870. Petrificata Suecana Formationis Cambricae. Acta Universitatis Lundensis, 2:1-14.

Uchman A., Janbu N.S., Nemec W. 2004. Trace fossils in the CretaceousEocene flysch of the Sinop-Boyabat basin, central Pontides, Turkey. Annales Societatis Geologorum Poloniae, 74:97-235.

Von Sternberg K.G. 1833.Versuch einer geognostisch-botanischen Darstellung der Flora der Vorwelt. IV Heft. C. E. Brenck, Regensburg., 5-6:1-80.

Walker R.G. 1984. Shelf and shallow marine sands. In: Walker R.G. (ed.) Facies Models. Geoscience Canada, Reprint Series. p.141-170.

Walker R.G. 2006. Facies models revisited. In: Posamentier R. W. \& Walker R.G. (eds.), Facies models revisited, SEPM Special Publication, 84:1-17

Weiss E. 1884. Vorlegung des Dictyophytum Liebeanum Gein. aus der Gegend Von Gera. Ber. Gen. naturf. Berlin, Freund. 17 p.

Wheatcroft R.A., Sommerfield C.K., Drake D.E., Borgeld J.C., Nittrouer C.A., 1997. Rapid and widespread dispersal of flood sediment on the northern California margin. Geology, 25:163-166.

Yamaguchi N. \& Sekiguchi, H. 2010. Effects of settling and preferential deposition of sediment on ripple roundness under shoaling waves. Journal of Sedimentary Research, 80:781-790.

Yang B.C., Dalrymple R.W., Chun S.S. 2006. The significance of hummocky crossstratification (HCS) wavelengths: Evidence from an open-coast tidal fl at, South Korea. Journal of Sedimentary Research, 76:2-8.

Yokokawa M., Masuda F., Endo N. 1995. Sand particle movement on migrating combined-flow ripples. Journal of Sedimentary Research 65:40-44.

Zenker J.C. 1836 (ed.) Historisch-topographisches Taschenbuch von Jena und seiner Umgebung besonders in naturwissenschafticher und medizinischer Beziehung. Wackenhoder, Jena. 338 p.

Arquivo digital disponível on-line no site www.sbgeo.org.br 
